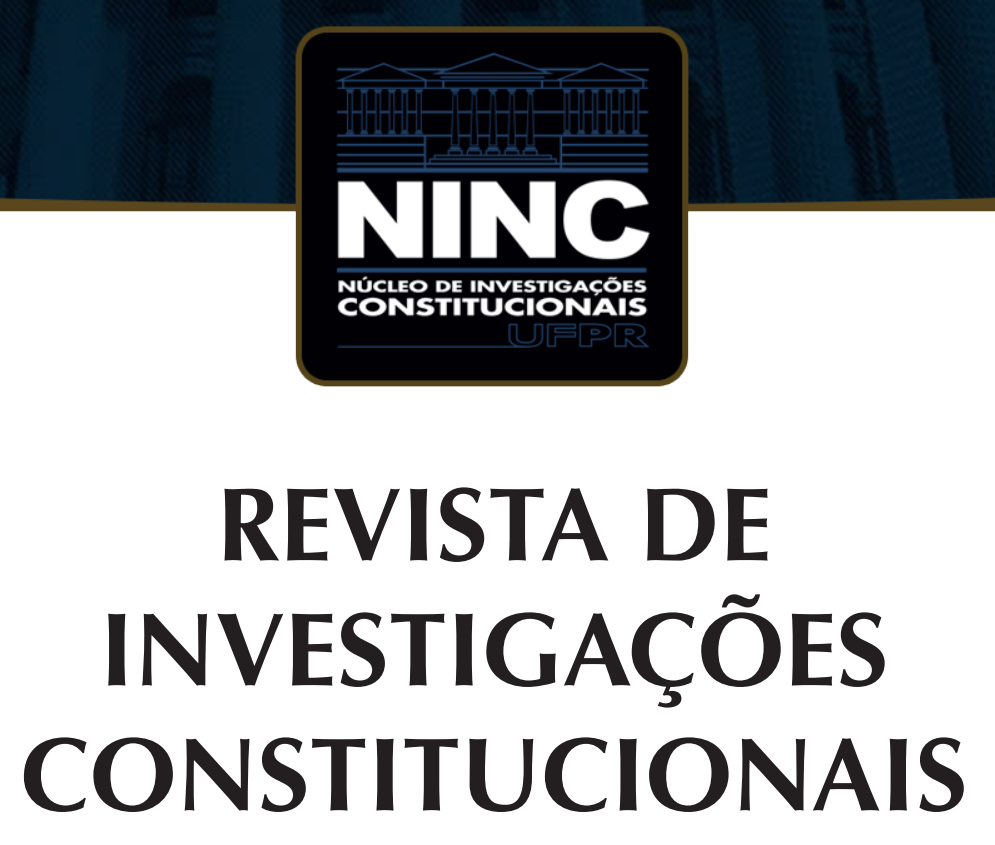

JOURNAL OF CONSTITUTIONAL RESEARCH

vol. 7 | n. 2 | maio/agosto 2020 | ISSN 2359-5639 | Periodicidade quadrimestral Curitiba | Núcleo de Investigações Constitucionais da UFPR | www.ninc.com.br 


\section{OSTF e o controle das leis sobre o regime jurídico das agências reguladoras federais}

\section{Brazilian Supreme Court and the review of statutes on federal regulatory agencies}

EDUARDO JORDÃO 1 ,

' Fundação Getúlio Vargas - FGV/RJ (Rio de Janeiro, Rio de Janeiro, Brasil) eduardo.jordao@fgv.br https://orcid.org/0000-0001-8440-101X

\section{RENATO TOLEDO CABRAL JUNIOR ${ }^{11, * *}$}

" Universidade do Estado do Rio de Janeiro (Rio de Janeiro, Rio de Janeiro, Brasil) toledocabral@gmail.com https://orcid.org/0000-0003-4106-7909

\section{LUIZA BRUMATI ${ }^{1, * *+1}$}

'Fundação Getúlio Vargas - FGV/RJ (Rio de Janeiro, Rio de Janeiro, Brasil) lubrumati@hotmail.com https://orcid.org/0000-0001-9593-2334

Recebido/Received: 17.08 .2019 / August $17^{\text {th }}, 2019$ Aprovado/Approved: $28.10 .2020 /$ October $28^{\text {th }}, 2020$

\footnotetext{
Como citar esse artigo/How to cite this article: JORDÃO, Eduardo; CABRAL JR., Renato Toledo; BRUMATI, Luiza. O STF e o controle das leis sobre o regime jurídico das agências reguladoras federais. Revista de Investigações Constitucionais, Curitiba, vol. 7 , n. 2, p. 549-600, maio/ago. 2020. DOI: 10.5380/rinc.v7i2.68568.
}

"Professor da Fundação Getúlio Vargas - FGV Direito Rio (Rio de Janeiro-RJ, Brasil). Doutor em Direito Público pelas Universidades de Paris 1 (Panthéon-Sorbonne) e de Roma (Sapienza), com pesquisas de pós-doutorado na Harvard Law School e no MIT Economics. Master of Laws (LL.M) pela London School of Economics and Political Science (LSE). Mestre em Direito Econômico pela Universidade de São Paulo (USP). Bacharel em Direito pela Universidade Federal da Bahia (UFBA). Foi pesquisador visitante na Yale Law School, nos Estados Unidos, e pesquisador bolsista nos Institutos Max-Planck de Heidelberg e de Hamburgo, na Alemanha. Sócio do Portugal Ribeiro Advogados. E-mail: eduardo.jordao@fgv.br.

${ }^{* *}$ Mestre em Direito Público pela Universidade do Estado do Rio de Janeiro (Rio de Janeiro-RJ, Brasil). Bacharel em Direito pela Universidade do Estado do Rio de Janeiro (UERJ). Assistente acadêmico na FGV Direito Rio. Membro-fundador do Laboratório de Regulação Econômica da UERJ (UERJ Reg.). Membro da Comissão Especial de Licitações e Contratos Administrativos da OAB/ RJ. Advogado. E-mail: toledocabral@gmail.com.

**** Acadêmica da Fundação Getúlio Vargas - FGV Direito Rio (Rio de Janeiro-RJ, Brasil). Bolsista do projeto "Regulação em Números". E-mail: lubrumati@hotmail.com. 
Resumo

Fruto do projeto "Regulação em Números", da FGV Direito Rio, este trabalho busca avaliar o papel do Supremo Tribunal Federal (STF) como foro de debate sobre o modelo das agências reguladoras no Brasil. $O$ tema é analisado em duas partes distintas, relativas às perspectivas dos postulantes e do STF. No primeiro caso, pretendeu-se verificar (i) quais atores buscam a invalidação ou a imposição de limites aos poderes das agências reguladoras pela via do controle abstrato de constitucionalidade de normas ("quem postula?"); (ii) quais são suas motivações ("por que postula?") e (iii) em que momento tais demandas são ajuizadas ("quando postula?"). As mesmas perguntas básicas se repetem no segundo caso: (i) quanto tempo as contestações levam tramitando e sendo deliberadas ("quando decidem?"); (ii) o que é examinado e com base em quais fundamentos eles decidem ("o que e como decidem?"); e (i) qual o comportamento e entendimento individual dos ministros frente a estas contestações ("quem e como decidem?"). Para responder a estas perguntas, foram lidas as 18 ações movidas perante o STF e as respectivas decisões da Corte que envolvem leis sobre o regime jurídico das agências reguladoras federais no país entre os anos de 1997 e 2018.

Palavras-chave: agências reguladoras; regime especial; Supremo Tribunal Federal; controle de constitucionalidade; jurisdição constitucional.

\section{Abstract}

A product of FGV Law School in Rio de Janeiro's project "Regulation in Numbers", this paper seeks to evaluate the role of the Supreme Court (STF) as a forum for debate on regulatory agencies in Brazil. The subject is analyzed in two distinct parts, concerning the perspectives of the claimants and the Supreme Court. In the first part, the paper asks (i) which actors seek to invalidate or impose limits on the powers of regulatory agencies through the abstract control of constitutionality of norms ("who postulates?"); (ii) what are their reasons ("why do they postulate?") and (iii) when are these claims filed ("when do they postulate?"). The same questions are repeated in the second part: (i) how long do these claim take to be processed and deliberated ("when does the Court decide?"); (ii) what is examined and on what grounds does the Court decide ("what and how does the Court decide?"); and (i) what is the individual behavior of the Justices regarding these claims ("who and how do Justices decide?"). In order to answer these questions, the 18 claims filed before the Supreme Court and the respective decisions of the Court involving statutes about the legal regime of federal regulatory agencies between 1997 and 2018.

Keywords: regulatory agencies; special legal regime; Supreme Court; control of constitutionality; constitutional jurisdiction.

\section{SUMÁRIO}

1. Introdução; 1.1. A reforma do Estado e a proliferação de agências reguladoras; 1.2. As agências reguladoras no Brasil; 1.3. Reação ao modelo das agências reguladoras; 1.4. Qual a relevância do Supremo Tribunal Federal no debate sobre o modelo das agências reguladoras? 1.5. A estrutura deste artigo; 2. Metodologia da pesquisa e síntese dos resultados; 2.1. O objeto da pesquisa; 2.2. Metodologia para definição da base de dados; 2.3. Os critérios de avaliação e a síntese dos resultados; 3 . O debate sobre as agências reguladoras no STF sob a ótima dos postulantes; 3.1. Quem postula? 3.1.1. A participação acentuada dos partidos políticos; 3.1.2. O setor regulado e os grupos de interesses sobre o funcionalismo político; 3.1.3. A Procuradora-Geral da República; 3.2. Por que postulam? 3.2.1. Contestação do regime jurídico especial das agências reguladoras; 3.2.2. Redução dos poderes e competências das agências reguladoras; 3.2.3. Um capítulo à parte: demandas relacionadas ao regime de pessoas das agências reguladoras; 3.3. Quando postulam? 3.4. Conclusões parciais em relação aos postulantes; 4. O debate sobre as agências reguladoras sob a ótima do processo decisório do STF.; 4.1. Quando decidem? 4.1.1. Casos julgados e linha do tempo; 4.1.2. Tempo de deliberação; 4.1.3. Tempo de tramitação; 4.2. $O$ que e como decidem? 4.2.1. O modelo institucional das agências reguladoras; 4.2.2. O poder normativo das agências reguladoras; 4.2.3. A autonomia e a eficiência gerencial das agências reguladoras; 4.2.4. Usurpação de competências de outros Poderes; 4.3. Quem e como decidem? 4.3.1. A conduta individual dos Ministros; 4.3.2. O posicionamento individual dos Ministros; 4.4. Conclusões parciais em relação ao STF; 5 . Conclusões; $\mathbf{6}$. Referências. 


\section{INTRODUÇÃO}

Este artigo é fruto do projeto denominado "Regulação em Números", da Escola de Direito do Rio de Janeiro da Fundação Getúlio Vargas (FGV Direito Rio). O objetivo central do trabalho é avaliar o papel do Supremo Tribunal Federal no contexto da implantação do Estado Regulador brasileiro. Para este fim, foram lidas e examinadas as ações movidas perante o STF em que foram impugnadas leis e medidas provisórias que disciplinam o regime jurídico especial das agências reguladoras federais no país.

De um lado, pretende-se avaliar o uso da jurisdição constitucional para questionar o modelo das agências reguladoras sob a perspectiva dos postulantes. Isto implica identificar: quais são os principais agentes que levaram ao Supremo Tribunal Federal discussões quanto à legitimidade das agências reguladoras no ordenamento constitucional brasileiro ("quem postula"); as razões que os levam a buscar a Corte Superior para questionar o modelo ("por que postulam"); e em que momento histórico decidem impugnar determinada legislação que disciplina o regime jurídico destas instituições ("quando postulam").

Da perspectiva da instituição, as mesmas perguntas básicas se repetem. Quis-se identificar (i) quanto tempo as contestações ao regime das agências levam tramitando e sendo deliberadas ("quando decidem"); (ii) quais temas foram decididos pelo Supremo Tribunal Federal e o respectivo entendimento firmado pela Corte ("o que e como decidem"); e (iii) qual o comportamento e posicionamento individual dos Ministros frente a estas contestações ("quem e como decide").

\subsection{A reforma do Estado e a proliferação de agências reguladoras}

A crise do Estado do bem-estar social resultou em período de intensa reforma administrativa nas últimas décadas do século XX. Antes considerado o principal agente da economia (sobretudo em seu modo de intervenção direta por meio de empresas estatais), o Estado teve seu papel reconfigurado num contexto de sucessivas privatizações e desestatizações. O processo foi acompanhado de necessidade cada vez maior de fiscalização das atividades que foram delegadas ao setor privado. Este movimento levou ao que se convencionou chamar de Estado regulador'.

\footnotetext{
1 MAJONE, Giandomenico. Do Estado positivo ao Estado regulador: causas e conseqüências de mudanças no modo de governança. Revista do Serviço Público, v. 50, n. 1, p. 5-36, 1999. Marçal Justen Filho identifica quatro distinções significativas entre essa nova concepção estatal diante do Estado de Providência: (i) a transferência para a iniciativa privada de atividades anteriormente desenvolvidas pelo Estado, inclusive com a liberalização de atividades até então monopolizadas; (ii) a preferência pelo instrumento interventivo indireto, por meio da regulação da atividades sociais e econômicas (competência regulatória); (iii) a atuação estatal norteada não apenas pelas correções das falhas de mercado, mas também admitindo-se a possibilidade de intervenção destinada a propiciar a realização de certos valores de natureza política e social; bem como (iv) a institucionalização de mecanismos de disciplina permanente das atividades reguladas. JUSTEN FILHO, Marçal. Curso de Direito Administrativo. 5. ed. Belo Horizonte: Fórum, 2011. p. 655.
} 
A liberalização de alguns setores da economia à iniciativa privada constituiu um processo extremamente complexo e sensível. Para capitaneá-lo, em vários países se optou pela criação das chamadas agências reguladoras - entidades relativamente independentes da administração central, com autonomia reforçada ${ }^{2}$, compostas por especialistas na matéria, com garantias de poder decisório insulado do processo político e dotadas de significativos recursos financeiros e humanos. Com esse modelo, a regulação de atividades econômicas antes submetidas ao monopólio estatal (como os serviços de telecomunicações, energia elétrica, gás, transporte ferroviário, etc.) passou a ser atribuída a instituição pública desenhada para lidar com a complexidade dessas funções ${ }^{3}$.

\subsection{As agências reguladoras no Brasil}

No Brasil, esse fenômeno se deu sobretudo no final da década de 1990 e no início da década seguinte ${ }^{4}$, especialmente durante o período de Reforma Administrativa e sob a vigência do chamado Plano Nacional de Desestatização (PND - Leis n 8.031/1990 e no 9.491/1997).

Esse modelo, no entanto, não encontrava respaldo expresso na Constituição Federal. O constituinte originário não concebeu o desenho das agências reguladoras. Limitou-se a prever no art. 174 o papel do Estado como agente normativo e regulador da atividade econômica 5 . Mesmo as emendas constitucionais editadas no período de Reforma Administrativa que previram a instituição de órgãos reguladores para o setor

2 ARAGÃO, Alexandre Santos de. Agências reguladoras e a evolução do direito administrativo econômico. 1. ed. Rio de Janeiro: Forense, 2002.

3 KING, Jeff A. Institutional approaches to judicial restraint. Oxford Journal of Legal Studies, vol. 28, n. 3, p. 409-441, 2008.

4 Confira-se, a propósito, o relato de Gustavo Binenbojm sobre o assunto: “Com efeito, a superação da crise econômico-gerencial do Estado brasileiro, cujo auge se atingiu na década de 1980, passava pela reformulação das estratégias de intervenção do Estado na economia. Através de desestatizações, privatizações e flexibilização de monopólios, o modelo de Estado empresário, calcado em forte intervenção direta na economia, foi substituído, a partir dos anos 1990, pelo modelo de Estado regulador, cuja intervenção opera-se de modo indireto. O sucesso da aludida conversão dependia, contudo, de maciça atração do capital privado, e, para tanto, fazia-se imprescindível superar a histórica crise de credibilidade do país e de suas instituições. Ou seja: era preciso vender o Brasil como um bom negócio, garantindo aos investidores a manutenção dos contratos celebrados e o direito de propriedade. Nisso reside, fundamentalmente, a razão da escolha pelo modelo de agências reguladoras: entidades com grau reforçado de autonomia, investidas de funções técnicas e, sobretudo, imunizadas das ingerências político-partidárias. Por outro lado, a transferência de serviços públicos e/ou de sua execução à iniciativa privada não poderia conduzir a um Estado puramente liberal, guiado pelo não-intervencionismo. Daí as agências constituírem também efeito da reforma por que passou o Estado brasileiro, na medida em que foram institucionalmente incumbidas da regulação tanto de serviços públicos desestatizados, como de outras atividades econômicas de relevante interesse social, devolvidas total ou parcialmente à iniciativa privada." (BINENBOJM, Gustavo. Uma Teoria do Direito Administrativo. 3. ed. Rio de Janeiro: Renovar. 2014, p. 266/267).

5 Art. 174. Como agente normativo e regulador da atividade econômica, o Estado exercerá, na forma da lei, as funções de fiscalização, incentivo e planejamento, sendo este determinante para o setor público e indicativo para o setor privado. 
de telecomunicações (EC nº 08/1995, que modificou a redação do art. 21, XI da CRFB) e para o setor de petróleo e gás natural (EC n 09/1995, que alterou a redação do art. 177, $\S 2^{\circ}$, inciso III da CRFB) não impuseram a regulação por meio de agências independentes; apenas previam que determinados setores da economia seriam regulamentados pela Administração Pública.

Foi apenas no âmbito infralegal que as agências reguladoras passaram a figurar na realidade normativa brasileira. A primeira delas foi a Agência Nacional de Energia Elétrica - ANEEL, instituída pela Lei no 9.427/1996. Em seguida, foram criadas a Agência Nacional de Telecomunicações - ANATEL (Lei 9.472/1997); a Agência Nacional do Petróleo, Gás Natural e Biocombustíveis - ANP (Lei 9.478/1997); a Agência Nacional de Vigilância Sanitária - ANVISA (Lei no 9.782/1999); a Agência Nacional de Agência Suplementar - ANS (Lei n 9.961/2000); a Agência Nacional de Águas - ANA (Lei nº 9.984/2000); a Agência Nacional de Transportes Terrestres - ANTT e a Agência Nacional de Transportes Aquaviários - ANTAQ (Lei no 10.233/2001); a Agência Nacional do Cinema (Medida Provisória n 2.228-1/2001); a Agência Nacional da Aviação Civil (Lei no 11.182/2005) e, mais recentemente, a Agência Nacional de Mineração - ANM (Lei nº 13.575/2017). Em todas os casos, as autoridades reguladoras foram reconhecidas como autarquias $^{6}$ sob regime especial.

Ao todo, há atualmente no Brasil onze agências reguladoras no âmbito federal, cujos desenhos institucionais estão em constante revisão. Exemplos disso são as ampliações das competências regulatórias da ANCINE (Lei n 12.485/2011) e da ANA (Medida

\footnotetext{
6 A base conceitual para o conceito de autarquia se encontra no art. 5, inciso I do Decreto-lei n 200/1967. Segundo o dispositivo, a autarquia é um o serviço autônomo, criado por lei, com personalidade jurídica, patrimônio e receita próprios, para executar atividades típicas da Administração Pública, que requeiram, para seu melhor funcionamento, gestão administrativa e financeira descentralizada. A peculiaridade das agências está justamente no regime especial desenhado para estas instituições.

7 Por aparente atecnica legislativa, a definição do regime especial é distinta em cada lei de criação das agências reguladoras. Veja-se, por exemplo, que a Lei da ANATEL caracteriza esse regime pela "independência administrativa, ausência de subordinação hierárquica, mandato fixo e estabilidade de seus dirigentes e autonomia financeira" (cf. art. $8^{\circ}, \S 2^{\circ}$ da Lei n 9.472/1997). Já a Lei da ANS a caracteriza pela "autonomia administrativa, financeira, patrimonial e de gestão de recursos humanos, autonomia nas suas decisões técnicas e mandato fixo de seus dirigentes" (cf. art. 1², parágrafo único da Lei n 9.961/2000. De todo modo, em todos os casos, é relevante notar que o regime especial delimita um espaço de relevante autonomia e independência para as agências reguladoras no ponto de vista político, gerencial e decisório (ao menos no campo normativo). Ainda cabe destaque que recentemente a Lei n 13.848/2019, a chamada "Lei Geral das Agências" pretendeu a uniformização da definição do regime especial, dispondo, em seu art. $3^{\circ}$, "A natureza especial conferida à agência reguladora é caracterizada pela ausência de tutela ou de subordinação hierárquica, pela autonomia funcional, decisória, administrativa e financeira e pela investidura a termo de seus dirigentes e estabilidade durante os mandatos, bem como pelas demais disposições constantes desta Lei ou de leis específicas voltadas à sua implementação.", garantindo as citadas autonomia e independência e a caracterização especifica de cada Lei.
}

8 A Lei no 12.485/2011, que disciplina a comunicação audiovisual de acesso condicionado, ampliou as competências da ANCINE, que passou a regular as atividades de programação e de empacotamento previstas no referido marco legal. 
Provisória no 844/2018 e Medida Provisória n 868/2018) ${ }^{9}$, bem como as recentes propostas de unificação da ANTT com a ANTAQ numa única agência de transportes ${ }^{10}$.

\subsection{Reação ao modelo das agências reguladoras}

A proliferação destas entidades administrativas especializadas gerou alguns desafios para a teoria do direito administrativo e do direito público. Naquilo que concerne a este artigo, diferentes atores políticos e econômicos passaram a questionar se o modelo das agências reguladoras seria compatível com a Constituição Federal e, mais especificamente, se tais instituições subvertiam ou não a separação de poderes, o princípio democrático e o princípio da legalidade.

No âmbito doutrinário, publicistas relevantes apresentaram fortes críticas às agências reguladoras. Celso Antônio Bandeira de Mello, por exemplo, além de considerar as agências reguladoras inconstitucionais, questionou duramente a extensão de mandatos de seus dirigentes para além de um mesmo período governamental. Segundo ele, a essência da República estaria na temporariedade dos mandatos e na possibilidade de a sociedade escolher governantes com orientações diversas dos governos precedentes. Nas suas palavras, o modelo desenhado para as agências reguladoras no Brasil era uma "fraude contra o próprio povo"11.

Maria Sylvia Di Pietro, por sua vez, embora contestasse a existência das agências reguladoras, adotou posição menos extrema sobre o assunto. Para ela, contudo, as agências reguladoras deveriam encontrar respaldo normativo expresso na Constituição Federal. Por isso, na sua visão, apenas a ANATEL e a ANP poderiam contar com a autonomia e a independência atribuídas às agências reguladoras. Quanto às demais, caberia a elas respeito aos mandamentos de todos os poderes da República, com ampla possibilidade de revisão de seus atos. ${ }^{12}$

\footnotetext{
9 A Medida Provisória no 844/2018 tinha por objetivo o marco legal do saneamento básico e alterar a Lei $n^{\circ}$ 9.984/2000, para atribuir à Agência Nacional de Águas competência para editar normas de referência nacionais sobre o serviço de saneamento básico. Referida medida provisória não foi aprovada pelo Congresso Nacional, motivo pelo qual sua vigência foi encerrada. A Medida Provisória n 868/2018, com redação similar, ainda se encontra vigente.

10 Segundo informações disponibilizadas na imprensa: "O ministro da Infraestrutura, Tarcísio Freitas, reafirmou a intenção do governo Jair Bolsonaro de unir a Agência Nacional de Transportes Terrestres (ANTT) com a Agência Nacional de Transportes Aguaviários (Antaq). A afirmação foi feita pelo ministro no pregão da B3, onde o governo realizou nesta manhã de sexta-feira, 15, o leilão de aeroportos - a primeira concessão do governo Bolsonaro. 'Estamos estudando outras possibilidades, a própria fusão de ANTT e Antaq. Não é um coisa definida, mas que está em estudo e vai ser feito se a gente perceber que há ganho para a regulação, afirmou". Disponível em https://istoe. com.br/correcao-infraestrutura-reforca-intencao-em-fusao-da-antt-com-antaq/. Acesso em 15 mar. 2019.

11 BANDEIRA DE MELLO, Celso Antônio. Curso de direito administrativo. 14. ed. São Paulo: Malheiros, 2002, p. $153 / 154$.

12 Confiram-se as afirmações da autora: "A primeira indagação diz respeito aos fundamentos jurídico-constitucionais para a delegação de função normativa às agências. As duas únicas agências que estão previstas na Constituição são a ANATEL e a ANP, com a referência à expressão órgão regulador contida nos artigos $21, \mathrm{XI}, \mathrm{e} 177, \S 2^{\circ}$,
} 
Outros autores defenderam a existência das agências reguladoras no Brasil ${ }^{13}$, propondo parâmetros para compatibilizá-las com os ditames da Constituição Federal ${ }^{14}$. O embate, contudo, não se limitou ao âmbito de livros e artigos sobre o tema, espraiando-se também para o Poder Judiciário.

\subsection{Qual a relevância do Supremo Tribunal Federal no debate sobre o modelo das agências reguladoras?}

A discussão sobre a legitimidade de tais instituições teve o Supremo Tribunal Federal como um de seus foros de debate. Como cabe ao STF o controle de constitucionalidade sobre leis e demais atos normativos com eficácia vinculante e erga omnes (art. $102, \S 2^{\circ}$ da CRFB), diversos atores passaram a questionar, perante a Suprema Corte, a compatibilidade das leis de criação destas agências com a Constituição Federal.

III. As demais não têm previsão constitucional, o que significa que a delegação está sendo feita pela lei instituidora da agência. Por isso mesmo, a função normativa que exercem não pode, sob pena de inconstitucionalidade, ser maior do que a exercida por qualquer outro órgão administrativo ou entidade da Administração Indireta. Elas nem podem regular matéria não disciplinada em lei, porque os regulamentos autônomos não têm fundamento constitucional no direito brasileiro, nem podem regulamentar leis, porque essa competência é privativa do Chefe do Poder Executivo e, se pudesse ser delegada, essa delegação teria que ser feita pela autoridade que detém o poder regulamentar e não pelo legislador" DI PIETRO, Maria Sylvia Zanella. Curso de direito administrativo. 24. ed. São Paulo: Atlas, 2011, p. 612.

13 É possível enumerar diversos trabalhos sobre as agências reguladoras desde a década de 1990 até os dias atuais. Confiram-se, por todos: CONFORTO, Glória. Descentralização e Regulação da Gestão de Serviços Públicos. Revista de Administração Pública - RAP, vol. 32, n. 1, p. 27-40, 1998; AZEVEDO, Eurico de Andrade. Agências Reguladoras. Revista de Direito Administrativo - RDA, Rio de Janeiro, n. 213, p. 141-148, jul./set. 1998; SOUTO, Marcos Juruena Villela. Agências reguladoras. Revista de Direito Administrativo - RDA, Rio de Janeiro, n. 216, p. 125-162, 1999; SUNDFELD, Carlos Ari. Introdução às Agências Reguladoras. In: Carlos Ari Sundfeld (Org.). Direito Administrativo Econômico. São Paulo, Malheiros, 2000, p. 17/38; MOREIRA NETO, Diogo de Figueiredo. Agências reguladoras. In: MOREIRA NETO, Diogo de Figueiredo. Mutações do Direito Administrativo. Rio de Janeiro: Renovar, 2000. p. 145-184; PEREZ, Marcos Augusto. As agências reguladoras no direito brasileiro. A\&C - Revista de Direito Administrativo \& Constitucional, Curitiba, ano 2, n. 5, p. 59-66, 2000; TÁCITO, Caio. Agências reguladoras da Administração. Revista de Direito Administrativo - RDA, Rio de Janeiro, n. 221, p. 1-5, 2000; MORAES, Alexandre de. Agências reguladoras. Fórum Administrativo, Belo Horizonte, vol. 1, n. 8, p. 1009-1016, 2001; ARAGÃO, Alexandre Santos de. O poder normativo das agências reguladoras. A\&C - Revista de Direito Administrativo \& Constitucional, Curitiba, ano 2, n. 7, p. 47-92, 2001; ARAGÃO, Alexandre Santos de. Agências reguladoras e a evolução do direito administrativo econômico. 1. ed. Rio de Janeiro: Forense, 2002; JUSTEN FILHO, Marçal. O Direito das Agências Reguladoras Independentes. São Paulo, SP: Dialética, 2002; BARROSO, Luís Roberto. Agências Reguladoras. Revista de Direito Administrativo - RDA, Rio de Janeiro, n. 229, p. 285-311, 2002; MARRARA, Thiago. A legalidade na relação entre ministérios e agências reguladoras. Revista da Faculdade de Direito da USP, São Paulo, n. 99, p. 723-746, jan./dez. 2004; WALD, Arnoldo. A autonomia das agências reguladoras. Consulex: Revista Jurídica, v. 8, n. 170, p. 42-43, fev. 2004; MARQUES NETO, Floriano de Azevedo. Agências Reguladoras Independentes: fundamentos e seu regime jurídico. 1. ed. Belo Horizonte: Fórum, 2005; MATTOS, Paulo Todescan Lessa. O Novo Estado Regulador no Brasil: eficiência e legitimidade. São Paulo: Singular, 2006; GUERRA, Sérgio. Agências Reguladoras: da organização administrativa piramidal à governança em rede. 1. ed. Belo Horizonte: Fórum, 2012.

14 Destaca-se, sobre o tema, a obra "Agências Reguladoras e Democracia", organizada por Gustavo Binenbojm, que contou com artigo dos autores Alexandre Santos de Aragão, Luís Roberto Barroso, Laís Calil, Egon Bockmann Moreira, Mariana Mota Prado, Joaquim Barbosa, Paulo Correa, Caio Mário da Silva Pereira Neto e Lauro Antonio Nogueira Soares Júnior. V. BINENBOJM, Gustavo (Coord.). Agências reguladoras e democracia. 1. ed. Rio de Janeiro: Lumen Juris, 2006. 
O objetivo deste artigo é documentar e examinar esse fenômeno, tanto sob a ótica de seus postulantes (isto é, aqueles que apresentaram demandas perante o STF para questionar o modelo das agências reguladoras) quanto sob a perspectiva do próprio Supremo Tribunal Federal enquanto instituição julgadora. Embora haja um número reduzido de ações diretas de inconstitucionalidade sobre o tema, é possível identificar variáveis que iluminam determinadas tendências de atuação sob ambos os enfoques sugeridos.

A importância desse estudo está em entender qual o papel da jurisdição constitucional e, mais especificamente, do Supremo Tribunal Federal como foro de debate sobre o modelo das agências reguladoras no Brasil. Na medida em que a história nos revela que há diversas formas de desestruturar uma agência reguladora mesmo com a manutenção de tais instituições no ordenamento legal ${ }^{15}$, este estudo tem o condão de iluminar em que medida o STF é uma engrenagem relevante para o desenvolvimento e consolidação de modelos institucionais específicos para a regulação econômica e social no país. É dizer: mesmo que, em uma análise contextual, seja possível vislumbrar pouca independência prática para as agências reguladoras no Brasil, certo é que sua existência pressupõe a própria validação do modelo institucional das autarquias em regime especial pela Corte Constitucional.

Por isso, este artigo se propõe a averiguar, sob a perspectiva dos postulantes, (i) quais atores buscam a invalidação ou a imposição de limites aos poderes das agências reguladoras pela via do controle abstrato de constitucionalidade de normas ("quem postula?"); (ii) quais são suas motivações ("por que postula?") e (iii) em que momento tais demandas são ajuizadas ("quando postula?"). As mesmas perguntas básicas se repetem na segunda parte, em que se adota a perspectiva do STF: (iii) quanto tempo as contestações levam tramitando e sendo deliberadas ("quando decidem?"); (ii) quais os objetos debatidos e com base em quais fundamentos eles decidem ("o que e como decidem?"); e (iii) qual o comportamento e o posicionamento individual dos ministros frente a estas contestações ("quem e como decide?"). Em suma, pretendeu-se investigar os elementos do passado para buscar indícios sobre o futuro, sobretudo porque o debate sobre a independência institucional das agências reguladoras volta constantemente à tona.

\subsection{A estrutura deste artigo}

Este artigo está estruturado da seguinte forma. Após esta introdução, o item 2 abordará o objeto da pesquisa, a sua metodologia, os critérios de avaliação e uma síntese das conclusões obtidas. Nos itens 3 e 4, então, serão exibidos os resultados a partir

15 Sobre o tema, v. JORDÃO, Eduardo; RIBEIRO, Maurício Portugal. Como desestruturar uma agência reguladora em passos simples. Revista Estudos Institucionais, v. 3, n. 1, p. 180-209, ago. 2017. 
de delimitações e classificações desenvolvidas pelos autores. No item 3, os dados serão analisados sob a ótica dos postulantes das ações, enquanto no item 4 serão avaliados os dados relativos à atuação do Supremo Tribunal Federal. No item 5, por fim, serão apresentadas as conclusões finais do trabalho e breves reflexões sobre o assunto.

\section{METODOLOGIA DA PESQUISA E SÍNTESE DOS RESULTADOS}

\subsection{O objeto da pesquisa}

Como já se afirmou acima, este artigo é fruto do projeto denominado "Regulação em Números", da Escola de Direito do Rio de Janeiro da Fundação Getulio Vargas (FGV Direito Rio). O objetivo do trabalho é avaliar o questionamento do modelo das agências reguladoras no Brasil perante o Supremo Tribunal Federal. Para este fim, foram lidas e examinadas todas as ações movidas perante o STF e as decisões da Corte que envolvem leis infraconstitucionais que tratem sobre o regime jurídico das agências reguladoras federais no país.

De logo, observe-se que este artigo se dispõe a analisar apenas leis (no seu sentido amplo, o que também abrange medidas provisórias) que tenham por objeto definir o regime jurídico das agências reguladoras federais. Este corte metodológico inclui as leis de criação das agências reguladoras, leis que ampliam as suas competências, como também outras leis que disciplinam o seu regime jurídico de forma específica (tal como o fez, v.g., a Lei no 9.986/2000, em que se adotava o regime celetista para os agentes públicos das agências reguladoras, e que foi questionada nas ADI n 2310 e 2315).

O objetivo é identificar em que medida o modelo das agências reguladoras é questionado em abstrato, e não por meio da contestação de atos concretos editados e promovidos pelas agências reguladoras ${ }^{16}$. Daí a escolha das ações movidas perante o Supremo Tribunal Federal, instituição a quem foi atribuída a capacidade institucional

16 No Brasil, alguns estudos sobre o controle judiciais das agências reguladoras vem sendo desenvolvidos. Um estudo do CNJ, por exemplo, analisou 1.371 ações judiciais em que foram questionadas decisões de agências reguladoras entre 1994 e 2010 e revelou que mais de $80 \%$ dos casos que tiveram seu mérito julgado pelos tribunais superiores foram favoráveis às agências - tão embora, no decorrer do processo, a incidência de decisões desfavoráveis esteja presente com alguma incidência. Segundo o relatório, a complexidade e o caráter estritamente técnicos das entidades administrativas autônomas é uma de suas razões de decidir. Juliano Maranhão, ao analisar o estudo, observa que (i) há uma supervalorização de questões procedimentais; (ii) os magistrados geralmente carecem de conhecimento técnico para resolver as questões; (iii) a dicotomia entre o direito público e privado dificulta a compreensão judicial sobre assuntos regulatórios complexos; e (iv) há uma insensibilidade ao raciocínio regulatório que, muitas vezes, leva o Poder Judiciário a um formalismo jurídico (Juliano Maranhão, A revisão judicial de decisões de agências regulatórias: jurisdição exclusiva?". In: PRADO, Mariana Mota (Org.). O Judiciário e o Estado Regulador Brasileiro. São Paulo: FGV Direito SP, 2016, p. 26-46). Ainda sobre o tema, v., por todos, WANG, Daniel Wei Liang; PALMA, Juliana Bonacorsi de; COLOMBO, Daniel Gama e. "Revisão judicial dos atos das agências reguladoras: uma análise de jurisprudência brasileira". In: SCHAPIRO, Mario Gomes (org.). Direito Econômico Regulatório. São Paulo: FGV, 2010, versão digital, p. 236-305. 
para avaliar a constitucionalidade objetiva de leis e atos normativos. Por outro lado, a escolha das agências federais se justifica pela sua importância na economia do país, o maior conhecimento geral sobre a sua existência (o que amplia, também, o debate sobre elas) e a presença de um maior número de entidades regulatórias independentes no Poder Executivo federal em comparação com os demais entes da Federação.

É preciso reconhecer, contudo, que a definição deste escopo encontra dificuldades e fragilidades não negligenciáveis. Isso porque importantes manifestações jurisprudenciais sobre o tema se deram em casos envolvendo agências estaduais (tal como na ADI no 1949, em que se legitimou o modelo de mandatos fixos dos dirigentes das entidades reguladoras independentes do Estado do Rio Grande do Sul ${ }^{17}$ ) ou em demandas em que se questionavam atos concretos das agências e leis estaduais que conflitavam com mandamentos normativos por elas editados ${ }^{18-19}$. Ainda assim, no entanto,

17 Ação direta de inconstitucionalidade. Agência Estadual de Regulação dos Serviços Públicos Delegados do Rio Grande do Sul (AGERGS). Necessidade de prévia aprovação pela Assembleia Legislativa da indicação dos conselheiros. Constitucionalidade. Demissão por atuação exclusiva do Poder Legislativo. Ofensa à separação dos poderes. Vácuo normativo. Necessidade de fixação das hipóteses de perda de mandato. Ação julgada parcialmente procedente. (...) 3. Ressalte-se, ademais, que conquanto seja necessária a participação do chefe do Executivo, a exoneração dos conselheiros das agências reguladoras também não pode ficar a critério discricionário desse Poder. Tal fato poderia subverter a própria natureza da autarquia especial, destinada à regulação e à fiscalização dos serviços públicos prestados no âmbito do ente político, tendo a lei lhe conferido certo grau de autonomia. (...) 5. A teor da norma geral, aplicável às agências federais, prevista no art. $9^{\circ}$ da Lei Federal $n^{\circ}$ 9.986/2000, uma vez que os dirigentes das agências reguladoras exercem mandato fixo, podem-se destacar como hipóteses gerais de perda do mandato: (i) a renúncia; (ii) a condenação judicial transitada em julgado e (iii) o procedimento administrativo disciplinar, sem prejuízo de outras hipóteses legais, as quais devem sempre observar a necessidade de motivação e de processo formal, não havendo espaço para discricionariedade pelo chefe do Executivo. 6. Ação julgada parcialmente procedente para declarar a inconstitucionalidade do art. $8^{\circ}$ da Lei estadual n॰ 10.931/97, em sua redação originária e naquela decorrente de alteração promovida pela Lei estadual n 11.292/98, fixando-se ainda, em razão da lacuna normativa na legislação estadual, que os membros do Conselho Superior da Agência Estadual de Regulação dos Serviços Públicos Delegados do Rio Grande do Sul (AGERGS) somente poderão ser destituídos, no curso de seus mandatos, em virtude de renúncia, de condenação judicial transitada em julgado, ou de processo administrativo disciplinar, sem prejuízo da superveniência de outras hipóteses legais, desde que observada a necessidade de motivação e de processo formal, não havendo espaço para discricionariedade pelo chefe do Executivo (ADI 1949, Rel. Min. Dias Toffoli, Tribunal Pleno, julgado em 17/09/2014, DJe 14/11/2014).

18 Basta notar que o mais recente julgamento colegiado sobre o tema pesquisado - a ADI n० 4784 - cita como precedentes os seguintes casos: ADI 1668/DF-MC, Relator Ministro Marco Aurélio, Tribunal Pleno, DJ 16.4.2004; RMS 28487/DF, Relator Ministro Dias Toffoli, 1. Turma, DJe 14.3.2013; ADI 4954/AC, Relator Ministro Marco Aurélio, Tribunal Pleno, DJe 30.10.2014; ADI 4949/RJ, Relator Ministro Ricardo Lewandowski, Tribunal Pleno, DJe 03.10.2014; ADI 4951/PI, Relator Ministro Teori Zavascki, DJe 26.11.2014; ADI 4.093/SP, Relatora Ministra Rosa Weber, Tribunal Pleno, DJe 30.10.2014. Destes, apenas a ADI no 1668 faz parte da base de dados consolidada.

19 Veja-se o exemplo da ADI n 4093, que tinha por objeto a Lei do Estado de São Paulo n 12.623/2007. Naquele caso, a discussão sobre a constitucionalidade sobre uma lei estadual levou ao debate sobre o poder regulatório da ANVISA, nos seguintes termos: "AÇÃO DIRETA DE INCONSTITUCIONALIDADE PROPOSTA PELO GOVERNADOR DO ESTADO DE SÃO PAULO. LEI ESTADUAL № 12.623/2007. DISCIPLINA DO COMÉRICIO DE ARTIGOS DE CONVENIÊNCIA EM FARMÁCIAS E DROGARIAS. USURPAÇÃO DA COMPETÊNCIA DA UNIÃO. IMPROCEDÊNCIA. (...) Às agências reguladoras não compete legislar, e sim promover a normatização dos setores cuja regulação lhes foi legalmente incumbida. A norma regulatória deve se compatibilizar com a ordem legal, integrar a espécie normativa primária, adaptando e especificando o seu conteúdo, e não substituí-la ao inovar na criação de direitos e obrigações. Em espaço que se revela qualitativamente diferente daquele em que exercida a competência legiferante, a competência regulatória é, no entanto, conformada pela ordem 
o recorte aqui realizado permite levantar diretrizes sobre a atuação da sociedade civil e do Supremo Tribunal Federal no debate em questão.

\subsection{Metodologia para definição da base de dados}

Para encontrar respostas a tais indagações, foi necessário analisar um amplo número de processos ajuizados perante o Supremo Tribunal Federal. O portal da Corte disponibiliza em seu site um campo de pesquisa em que é possível identificar, a partir dos termos definidos pelo usuário, quais ações de controle concentrado foram ajuizadas. Para tanto, utilizaram-se os nomes de cada uma das agências reguladoras, o termo genérico "agência reguladora" (no plural e singular) e diferentes variações dos números das leis criadoras de cada agência reguladora para delimitar o primeiro espaço amostral da pesquisa. O limite temporal estabelecido para tanto foi o dia 31/12/2018, tendo em vista o período em que as pesquisas foram realizadas. Com isso, foram encontradas centenas de ações de controle concentrado (ADI, ADC, ADO e ADPF) sobre o tema.

A partir de então, a pesquisa envolveu a leitura da ementa das ações identificadas, de suas petições iniciais, de seus acompanhamentos processuais, de suas decisões liminares e dos acórdãos proferidos no curso de cada ação. Foram eliminadas todas as ações que, embora fizessem menções aos termos pesquisados, não guardavam pertinência com o objeto de pesquisa. Esta medida foi especialmente importante já na etapa inicial das pesquisas, na medida em que diversas leis que criaram agências reguladoras também estipulam regras sobre o marco regulatório do setor econômico no geral. Daí a necessidade de realização de um exame crítico de cada uma das ações com o objetivo de delimitar com precisão a base de dados sobre a qual o estudo se debruçaria. ${ }^{20}$

Além disso, mesmo ações diretas que questionaram leis e dispositivos específicos sobre as competências das agências reguladoras federais foram excluídas do espaço amostral em razão do fundamento adotado pelos autores das ADI. O objetivo deste corte foi delimitar um espaço amostral em que a intenção dos requerentes das ações foi obter um provimento de mérito do Supremo Tribunal Federal sobre a invalidade material do desenho institucional ou de determinado aspecto relativo à agência reguladora.

\footnotetext{
constitucional e legal vigente. As normas da ANVISA que extrapolem sua competência normativa - como é o caso da proibição de comércio de artigos de conveniência em farmácias e drogarias - não se revelam aptas a obstar a atividade legiferante dos entes federados. Ação direta de inconstitucionalidade julgada improcedente. (ADI 4093, Rel. Min. Rosa Weber, Tribunal Pleno, julgado em 24/09/2014, DJe 17/10/2014. Grifos nossos).

20 A título de exemplo, parte das ações diretas encontradas com os termos de pesquisa se relacionam com marcos regulatórios setoriais, embora não tratem especificamente sobre as agências reguladoras responsáveis para supervisionar a matéria. É o caso de ações que discutem sobre royalties sobre o petróleo (e.g., ADIs n ${ }^{\text {os }}$ 5936, 5621, 5038, 4920, 4918 e 4917); sobre questões ao setor de infraestrutura de telecomunicações (e.g., ADls $\mathrm{n}^{\text {os }} 1863$ e 1840); ou de normas sobre serviços de acesso condicionado que não necessariamente contestam o regime jurídico da ANCINE (e.g., ADIs n ${ }^{\text {os }} 4923,4756,4747$ e 4703).
} 
Na ADI n 3465 e na ADI n 3326, por exemplo, questionou-se a ampliação da competência da ANP, mas apenas por questões formais. É que a Medida Provisória nº 227/2004 estabelecia, em seu art. 11, a competência da ANP para estabelecer os termos e as condições de marcação do biodiesel, para sua identificação e delimitação do percentual de biodiesel ao óleo diesel derivado do petróleo, observadas as diretrizes estabelecidas pelo Conselho Nacional de Política Energética. Segundo o autor das ações - o Partido da Frente Liberal (PFL), atualmente Democratas (DEM) - o dispositivo em questão seria inconstitucional na medida em que a Constituição Federal, em seu art. $177, \S 2^{\circ}$, III, seu art. 246 e o art. $3^{\circ}$ da Emenda Constitucional nº 09/1995, vedaria a edição de medida provisória sobre tal matéria. Assim, embora o dispositivo impugnado tenha relação com a competência regulatória da ANP sobre o mercado de biodiesel, o fundamento apresentado pelo partido político não tinha por pretensão impugnar o regime jurídico da agência reguladora sob qualquer aspecto. $O$ mesmo se deu, por exemplo, no bojo da ADI n 3090, em demanda relativa à ampliação de competências da ANEEL pela Medida Provisória n 144/2003. Por tal circunstância, as aludidas ações foram excluídas do objeto de análise deste artigo.

Ao final, chegou-se ao resultado de 18 ações diretas de inconstitucionalidade, envolvendo a ANATEL (2), a ANTT (4), a ANTAQ (2), a ANP (3), a ANCINE (1), a ANVISA (1), a ANA (2) e todas as agências em uma mesma ação (4), conforme tabela a seguir:

\begin{tabular}{|c|c|c|}
\hline ADI & Agência Reguladora & Lei \\
\hline 6033 & Todas & Lei $10.871 / 2004$ \\
\hline 6006 & ANA & Medida Provisória $n^{\circ} 844 / 2018$ \\
\hline 5993 & ANA & Medida Provisória $n^{\circ} 844 / 2018$ \\
\hline 5906 & ANTT & Lei $n^{\circ} 10.233 / 2001$ \\
\hline 5372 & ANTT & Lei $10.233 / 2001$ \\
\hline 5371 & ANTT e ANTAQ & Lei $n^{\circ} 9.782 / 1999$ \\
\hline 4874 & ANVISA & Lei $n^{\circ} 12.996 / 2014 ;$ Lei $n^{\circ} 10.233 / 2001$ \\
\hline 4679 & ANCINE & Lei $n^{\circ} 9.478 / 1997$ \\
\hline 4226 & ANATEL & Lei $n^{\circ} 9.478 / 1997$ \\
\hline 3596 & ANP & Lei $n^{\circ} 9478 / 1997$ \\
\hline 3366 & ANP & L.472/1997; Lei $n^{\circ} 10.871 / 2004$ \\
\hline 3273 & ANP & \\
\hline
\end{tabular}




\begin{tabular}{|c|c|c|}
\hline 3240 & Todas & Lei $\mathrm{n}^{\circ} 10.871 / 2004$ \\
\hline 2658 & ANVISA & Medida Provisória $\mathrm{n}^{\circ} 2190-34 / 2001$ \\
\hline 2543 & ANTT e ANTAQ & Lei $\mathrm{n}^{\circ} 10.233 / 2001$ \\
\hline 2315 & Todas & Lei $\mathrm{n}^{\circ} 9.986 / 2000$ \\
\hline 2310 & Todas & Lei $\mathrm{n}^{\circ} 9.986 / 2000$ \\
\hline 1668 & ANATEL & Lei $\mathrm{n}^{\circ} 9472 / 1997$ \\
\hline
\end{tabular}

\subsection{Os critérios de avaliação e a síntese dos resultados}

Uma vez estabelecida a base de dados, os casos foram destrinchados e classificados a partir das seguintes variáveis: (i) número do processo no STF; (ii) agência reguladora envolvida; (iii) assunto do processo; (iv) lei questionada; (v) dispositivos legais questionados; (vi) data da publicação da lei; (vii) data da distribuição da ação; (viii) tempo de reação entre a data de distribuição da ação e a data de publicação da lei; (ix) requerente da ação; (x) dispositivos constitucionais invocados; (xi) relator da ação; (xii) existência de julgamento liminar e, em caso positivo, (xiii) seu resultado; e (xiv) data em que a decisão foi proferida; elementos também reproduzidos no caso das decisões de mérito (variáveis xv, xvi e xvii). Além disso, foi delimitado (xviii) o tempo de julgamento final nos casos em que houve julgamento final; ou, (xix) o tempo em que o processo se encontra em trâmite perante o STF sem decisão final, considerando como marco limite o dia 31/12/2018, tendo em vista o limite temporal estabelecido para a elaboração dos estudos e deste artigo.

Em síntese, a despeito do reduzido número de processos de controle concentrado examinados para a pesquisa, foi possível observar que (i) as ações são dominadas por partidos políticos, a despeito de associações dos setores regulados apresentarem uma crescente participação nestes processos. Além disso, (ii) embora a existência das agências reguladoras tenha sido contestada em abstrato no início do seu surgimento, as ações diretas de inconstitucionalidade se sofisticaram com o tempo e apresentam demandas sobre aspectos específicos de seus regimes jurídicos, com o objetivo de impor limites à sua atuação. Por fim, foi possível verificar que (iii) partidos políticos possuem a tendência de contestar os atos normativos criadores de competências de agências reguladoras em um curto espaço de tempo desde sua edição, enquanto associações e federações tem pretensões em tempos consideravelmente mais extensos, muitas vezes em razão de elementos contextuais da atividade concreta da agência reguladora.

Já em relação ao Supremo Tribunal Federal, é possível notar que a Corte desempenhou (e ainda desempenha) papel relevante na consolidação do modelo das agências reguladoras no Brasil, processo este ainda em andamento. Nos cinco casos em que 
houve julgamento pelo Plenário (ADI no 1668, 3273, 3366, 4679 e 4874), o Tribunal validou o modelo das agências reguladoras, embora alguns ministros tenham apresentado cautelas quanto à extensão da independência de tais instituições. De um modo geral, foram identificadas como diretrizes da jurisprudência da Corte (i) a constitucionalidade da atribuição de competências técnicas às agências reguladoras; (ii) a necessidade de que seus poderes estejam sujeitos à observância dos parâmetros previstos em leis (a ideia de "princípios inteligíveis"); e (iii) sua independência não afasta a possibilidade de posterior controle de seus atos, embora seja recomendável a adoção de uma postura deferente do Poder Judiciário.

Estabelecidas tais premissas, passa-se à análise efetiva dos resultados da pesquisa.

\section{O DEBATE SOBRE AS AGÊNCIAS REGULADORAS NO STF SOB A ÓTICA DOS POSTULANTES}

Conforme apresentado anteriormente, este item do artigo se destina a analisar os dados relacionados aos postulantes de demandas perante o Supremo Tribunal Federal que tratem sobre o regime jurídico das agências reguladoras. Mais especificamente, os subitens a seguir avaliarão (i) quem são os autores das ADIs identificadas na base de dados estipulada na pesquisa; (ii) os pedidos e razões apresentados por estes autores em suas petições iniciais; bem como (iii) o momento em que se postula a invalidação de determinada norma sobre as agências reguladoras federais. Em cada um destes pontos, os autores deste artigo procurarão apresentar dados contextuais sobre as ações, sempre que entenderem pertinentes para situar o leitor.

\subsection{Quem postula?}

A primeira pergunta a ser respondida por este artigo está relacionada aos agentes que litigam perante o Supremo Tribunal Federal para questionar o regime jurídico especial das agências reguladoras. Sobre esse tema, a tabela a seguir estipula o requerente de cada uma das ADIs identificadas na pesquisa:

\begin{tabular}{|c|c|c|}
\hline Número & Agência Reguladora & Requerente \\
\hline 6033 & Todas & $\begin{array}{c}\text { ASSOCIACAO NACIONAL DOS SERVIDORES } \\
\text { EFETIVOS DAS AGENCIAS REGULADORAS } \\
\text { FEDERAIS - ANER }\end{array}$ \\
\hline 6006 & ANA & PARTIDO DOS TRABALHADORES - PT \\
\hline 5993 & ANA & PARTIDO SOCIALISTA BRASILEIRO - PSB \\
\hline
\end{tabular}




\begin{tabular}{|c|c|c|}
\hline 5906 & ANTT & $\begin{array}{c}\text { ASSOCIACAO BRASILEIRA DAS EMPRESAS DE } \\
\text { TRANSPORTE TERRESTRE DE PASSAGEIROS - } \\
\text { ABRATI }\end{array}$ \\
\hline 5371 & ANTT e ANTAQ & PROCURADORIA GERAL DA REPÚBLICA \\
\hline 5372 & ANTT & $\begin{array}{l}\text { CONFEDERAÇÃO NACIONAL DOS USUÁRIOS } \\
\text { DE TRANSPORTES COLETIVOS RODOVIÁRIOS, } \\
\text { FERROVIÁRIO, HIDROVIÁRIO E AÉREO - CONUT }\end{array}$ \\
\hline 4874 & ANVISA & $\begin{array}{c}\text { CONFEDERAÇÃO NACIONAL DA INDÚSTRIA } \\
-\mathrm{CNI}\end{array}$ \\
\hline 4679 & ANCINE & DEMOCRATAS - DEM \\
\hline 4226 & ANATEL & $\begin{array}{l}\text { ASSOCIAÇÃO BRASILEIRA DOS PROVEDORES } \\
\text { DE INTERNET E OPERADORES DE COMUNICA- } \\
\text { ÇÃO DE DADOS MULTIMIIDIA - ABRAMULTI }\end{array}$ \\
\hline 3596 & ANP & PARTIDO SOCIALISMO E LIBERDADE - PSOL \\
\hline 3366 & ANP & PARTIDO DEMOCRÁTICO TRABALHISTA - PDT \\
\hline 3273 & ANP & GOVERNADOR DO ESTADO DO PARANÁ \\
\hline 3240 & Todas & DEMOCRATAS - DEM \\
\hline 2658 & ANVISA & $\begin{array}{c}\text { CONFEDERAÇÃO NACIONAL DO COMÉRCIO } \\
\text { - CNC }\end{array}$ \\
\hline 2543 & ANTT e ANTAQ & $\begin{array}{c}\text { ASSOCIAÇÃO BRASILEIRA DE ENGENHEIROS } \\
\text { RODOVIÁRIOS - ABER }\end{array}$ \\
\hline 2315 & Todas & PARTIDO DEMOCRÁTICO TRABALHISTA - PDT \\
\hline 2310 & Todas & PARTIDO DOS TRABALHADORES - PT \\
\hline 1668 & ANATEL & $\begin{array}{l}\text { PARTIDO COMUNISTA DO BRASIL - PC do B; } \\
\text { PARTIDO DOS TRABALHADORES - PT; PARTIDO } \\
\text { DEMOCRÁTICO TRABALHISTA - PDT; PARTIDO } \\
\text { SOCIALISTA BRASILEIRO - PSB }\end{array}$ \\
\hline
\end{tabular}

A base de dados demonstra que as ações relativas ao modelo institucional das agências reguladoras estão concentradas especialmente no campo político. De um total de dezoito ADls, nove foram movidas por partidos políticos (ADIs $n^{\circ} 6006, n^{\circ} 5993$,

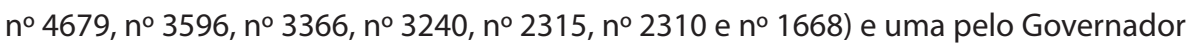
do Estado do Paraná (ADI no 3273).

Além disso, cinco medidas foram apresentadas pelo setor regulado, tanto por meio de associações representantes de uma categoria específica - casos da ABRATI (ADI n 5906), da CONUT (ADI n 5372) e da ABRAMULTI (ADI n 4226) - como por 
confederações de legitimidade ampla - casos da CNI (ADI n4.874) e da CNC (ADI nº 2.658). Foi possível identificar, ainda, duas ações movidas por grupos de interesse relacionados ao funcionalismo público - a ANER (ADI n6033) e a ABER (ADI n²543). Por fim, aponte-se uma ação ajuizada pela Procuradoria Geral da República (ADI n 5371).

\subsubsection{A participação acentuada dos partidos políticos}

Como é possível notar, mais da metade das ADIs relativas ao regime jurídico das agências reguladoras federais foram ajuizadas por partidos políticos. Quanto ao espectro político de tais partidos, é possível afirmar, ainda, que as ações estão concentradas em partidos de orientação de esquerda. Basta notar que, entre os partidos políticos que apresentaram demandas perante o Supremo Tribunal Federal ao longo do período pesquisado, sete entre nove ADIs foram ajuizadas pelo Partido dos Trabalhadores (PT); pelo Partido Comunista do Brasil (PC do B); pelo Partido Democrático Trabalhista (PDT); pelo Partido Socialista Brasileiro (PSB) e pelo Partido Socialismo e Liberdade (PSOL). Até mesmo a ADI n॰ 3273 foi movida pelo então Governador do Estado do Paraná Roberto Requião, que, embora seja membro de um partido considerado de centro-direita (o Movimento Democrático Brasileiro - MDB, ex-PMDB), apresenta clara orientação política pessoal de esquerda ${ }^{21}$. Apenas duas ações foram movidas, por sua vez, por partido mais à direita do espectro político nacional - o Democratas (DEM).

\begin{tabular}{|c|c|c|c|}
\hline ADI & Ano & Governo & Partido político \\
\hline 6006 & 2018 & Michel Temer & PT \\
\hline 5993 & 2018 & Michel Temer & PSB \\
\hline 4679 & 2011 & Dilma Rousseff & PSOL \\
\hline 3596 & 2005 & Luís Inácio Lula da Silva & PDT \\
\hline 3366 & 2004 & Luís Inácio Lula da Silva & Luís Inácio Lula da Silva \\
\hline 3273 & 2004 & Luís Inácio Lula da Silva & do Paraná \\
\hline 3240 & 2004 & Fernando Henrique Cardoso & PDT \\
\hline 2315 & 2000 & Fernando Henrique Cardoso & PT \\
\hline 2310 & 2000 & Fernando Henrique Cardoso & PT, PC do B, PDT e PSB \\
\hline 1668 & 1997 &
\end{tabular}

21 Veja em "Roberto Requião critica projeto de Temer 'neoliberal"'. Disponível em <https://bit.ly/30JJs3Y>. Acesso em 19.03.2019. Há, ainda, manifestações públicas do deputado a favor da orientação política de esquerda, como a seguinte: "Esquerda é olhar o mundo pelas lentes dos mais pobres e mais fracos. Esquerda é amor e solidariedade. Direita é egoismo e individualismo" (publicação no twitter em 22/05/2017). 
Não é surpreendente que partidos de esquerda se destaquem na contestação do modelo das agências reguladoras. O Partido dos Trabalhadores, em especial, sempre Ihe foi abertamente contrário. O PT e o PDT foram os principais responsáveis, autonomamente ou em conjunto com outros partidos de oposição, pelo ajuizamento de ações no período do governo Fernando Henrique Cardoso (1995-2002). ${ }^{22}$

No início de 2003, ao assumir seu primeiro mandato presidencial, o presidente Lula declarou que agências reguladoras estavam independentes demais ${ }^{23}$ e que as decisões que mais afetavam a população não passavam pelo seu governo. No caso mais notório, o governo conseguiu induzir a renúncia de Luiz Guilherme Schymura da presidência da ANATEL, após duras críticas das medidas de reajustes tarifários dos serviços de telecomunicações por ele intentadas ${ }^{24}$. Em paralelo, o governo petista também propôs alterações legislativas na estrutura das agências reguladoras ${ }^{25}$.

A resistência ao modelo das agências também pode ser identificada pela escassa criação de tais instituições durante a gestão dos governos de Lula (2003-2009) e de Dilma Roussef (2010-2016). Neste ínterim, apenas uma agência reguladora foi criada: a ANAC, por meio da Lei no 11.182/2005. Isso não impediu que o então presidente Lula criticasse a atuação desta agência reguladora na mídia. Em 2007, ele afirmava que a

22 Em entrevista para a Revista Veja, o ex-presidente Fernando Henrique Cardoso, cujo governo foi responsável pela implementação de tais instituições no Brasil, afirmou que "o governo do PT nunca entendeu a função das agências reguladoras" Segundo ele, a má compreensão se referia não apenas às contestações feitas pelo partido durante o período de reforma estatal, mas principalmente pelo então governo do presidente Luiz Inácio Lula da Silva, que tomava, segundo ele, atitudes com o objetivo de enfraquecer o poder decisório das

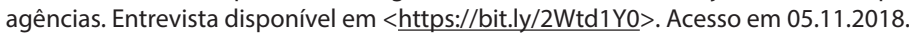

23 Jornal Nacional. "Lula quer mudar o papel das agências reguladoras”. Publicado em 22.02.2003. Disponível em <https://glo.bo/30CVR9l>. Acesso em 05.11.2018.

24 Agência Brasil. "Schymura renuncia à vaga no conselho da Anatel". Disponível em < https://bit.ly/2Qobltu > Acesso em 19.03.2019.

25 Confira-se o relato de Gustavo Binenbojm: "Logo em seguida, em março de 2003, Lula designou uma comissão para discutir uma proposta legislativa de reforma da estrutura das agências. De outra parte, o governo iniciou um acalorado debate público com as agências de telecomunicações (ANATEL) e energia elétrica (ANEEL) tendo por objeto a revisão das tarifas telefônicas e de energia, cujo exame se encontrava em curso. Por evidente. não interessava a um governo popular que, logo em seu começo, medidas impopulares - como o aumento de tarifas - fossem determinadas pelas agências. Na percepção da opinião pública, tais medidas seriam certamente atribuídas ao governo como um todo" (BINENBOJM, Gustavo. Uma Teoria do Direito Administrativo. 3. ed. Rio de Janeiro: Renovar, 2014, p. 287/288). Em seguida, o governo Lula apresentou ao Congresso Nacional o Projeto de Lei $n^{\circ}$ 3.337/2004, que, segundo a sua exposição de motivos, tinha por objetivo "estabelecer um conjunto homogêneo e estável de regras para orientar a gestão e a atuação das agências reguladoras a fim de superar as diferenciações entre elas que não se justificam e tornar mais transparente, eficiente, socialmente controlado e legítimo o exercício da regulação". Segundo estudos específicos sobre o PL, o objetivo do governo foi criar mecanismos de tutela da Administração Pública direta sobre as agências reguladoras (LOURENÇO, Adriana Nickel. Regendo a atividade regulatória: a nova legislação das agências reguladoras federais no Brasil. Dissertação (Mestrado em Administração Pública), 2010. Escola Brasileira de Administração Pública e de Empresas - Fundação Getúlio Vargas. Disponível em <https://bit.ly/2EzyPqP>. Acesso em 19 mar. 2019.) 
agência, criada para defender os passageiros, fora capturada pelos interesses das empresas aéreas ${ }^{26}$, sugerindo uma possível demissão de todos os seus cinco diretores ${ }^{27}$.

Durante o governo do presidente Michel Temer (2016-2018), o modelo institucional das agências reguladoras voltou a debate por força de duas inovações legislativas promovidas pelo governo federal. A primeira, com a edição da Medida Provisória n 791/2017, que transformou o Departamento Nacional de Produção Mineral - DNPM, órgão vinculado ao Ministério de Minas e Energia, na Agência Nacional de Mineração - ANM. A segunda, com a edição das Medidas Provisórias n 868 e n 884/2017, que ampliaram a competência da Agência Nacional de Águas - ANA, atribuindo-lhe o poder para estabelecer normas de referência nacionais para a regulação da prestação dos serviços públicos de saneamento básico. As novas competências da ANA também foram motivo para que partidos de esquerda (PT e PSB) retomassem o ajuizamento de ações em busca de um pronunciamento do Supremo Tribunal Federal sobre a inconstitucionalidade das medidas.

Por outro lado, ambas as ações ajuizadas pelo DEM se deram no período de governos do Partido dos Trabalhadores. ${ }^{28}$ Isso sugere que, independentemente da ideologia adotada pelo partido, o ajuizamento de ADIs contra leis que disciplinam o regime jurídico das agências reguladoras pode constituir um importante instrumento de uso político.

\subsubsection{O setor regulado e os grupos de interesses sobre o funcionalismo público}

Embora a contestação do regime jurídico especial das agências reguladoras se dê majoritariamente no campo político, há outros atores que encontraram no Supremo Tribunal Federal uma via para contestar aspectos específicos das competências destas instituições. É possível destacar dois grupos distintos nesse campo: (i) associações, federações e confederações que representam o setor regulado e contestam os limites dos poderes das agências responsáveis por regulamentar a atividade econômica por eles exercida; (ii) grupos de interesses sobre o funcionalismo público, também

\footnotetext{
26 O Globo. "Irritado com a Anac, Lula anuncia medidas fortes amanhã". Disponível em: $<$ https://glo.bo/2HCKXJX>. Acesso em 19.03.2019.

27 O Estado de São Paulo. "Sem poder para demitir, Lula pede aos 5 diretores da Anac que saiam". Disponível em: $<$ https://bit.ly/2QtWeyU $>$. Acesso em 19.03.2019.

28 A atuação do partido não é necessariamente um contrassenso. A primeira ADI ajuizada pelo partido questionou o art. 30 da Lei no 10.871/2004, que permitia contratações temporárias de servidores por agências reguladoras (ADI n 3240). Embora envolva a autonomia gerencial destas instituições, a medida não necessariamente possui um discurso anti-agências. Já a ADI n 4679, em face de dispositivos da Lei n 12.485/2011. Um dos fundamentos apresentados foi a violação à liberdade de expressão e à liberdade artística (art. $5^{\circ}$, IX e art. 220 , caput e $\S 3^{\circ}$ ), assim como a liberdade de iniciativa e a livre concorrência (art. 170, caput e inciso IV), valores estes defendidos pelo partido. Ainda assim, em especial na ADI n० 4679, a atuação do DEM para a declaração da inconstitucionalidade do poder normativo da ANCINE não deixa de ser um movimento tendente a fragilizar o regime jurídico das agências reguladoras.
} 
representado por associações, que têm por objetivo impugnar aspectos relacionados ao regime jurídico dos agentes públicos das agências reguladoras.

\subsubsection{A Procuradoria-Geral da República}

A Procuradoria-Geral da República, legitimada universal para o ajuizamento de ações de controle abstrato (art. 103, inciso VI, CRFB), ajuizou uma das ações identificadas na base de dados.

\subsection{Por que postulam?}

A segunda pergunta a ser respondida por este artigo está relacionada à motivação dos agentes que litigam perante o Supremo Tribunal Federal para questionar o regime jurídico das agências reguladoras. Sobre esse tema, a tabela a seguir estipula o assunto de cada uma das ADIs incluídas na pesquisa:

\begin{tabular}{|c|c|}
\hline Número & Assunto \\
\hline 6033 & $\begin{array}{c}\text { Agentes públicos de agências reguladoras requerem a possibilidade de } \\
\text { exercer atividade profissional, inclusive gestão operacional de empresa, } \\
\text { ou direção político-partidária, excetuados os casos admitidos em lei. }\end{array}$ \\
\hline 6006 & $\begin{array}{c}\text { Ampliação das competências da ANA para regulação das diretrizes para o } \\
\text { saneamento básico. }\end{array}$ \\
\hline 5993 & $\begin{array}{c}\text { Ampliação das competências da ANA para regulação das diretrizes para o } \\
\text { saneamento básico. }\end{array}$ \\
\hline 5906 & $\begin{array}{c}\text { Invalidade da delegação às agências reguladoras de competência para a } \\
\text { criação de figuras infracionais por resoluções. }\end{array}$ \\
\hline 5372 & $\begin{array}{c}\text { Competência da ANTT para regular transporte rodoviário coletivo regular } \\
\text { interestadual e internacional de passageiros. }\end{array}$ \\
\hline 5371 & Sigilo nos processos administrativos sancionadores da ANTT e da ANTAQ \\
\hline 4874 & $\begin{array}{c}\text { Competência da ANVISA para proibir, em caráter genérico e abstrato, a } \\
\text { fabricação e comercialização de produtos e insumos submetidos à fiscali- } \\
\text { zação sanitária. }\end{array}$ \\
\hline 4679 & $\begin{array}{c}\text { Competência da ANCINE para regular o setor audiovisual de acesso con- } \\
\text { dicionado. }\end{array}$ \\
\hline 4226 & $\begin{array}{c}\text { Competência da ANATEL para proferir decisões cautelares de busca e } \\
\text { apreensão de bens. }\end{array}$ \\
\hline 3596 & Competência normativa da ANP. \\
\hline 3366 & $\begin{array}{c}\text { Competência da ANP para autorizar a exportação de petróleo; regra de } \\
\text { silêncio administrativo no processo decisório da ANP. }\end{array}$ \\
\hline
\end{tabular}




\begin{tabular}{|c|r|}
\hline 3273 & $\begin{array}{r}\text { Competência da ANP para autorizar a exportação de petróleo; regra de } \\
\text { silêncio administrativo no processo decisório da ANP. }\end{array}$ \\
\hline 3240 & Contratação temporária de servidores das agências reguladoras. \\
\hline 2658 & Competência da ANVISA para fiscalizar farmácias e drogarias. \\
\hline 2543 & Regime celetista para os agentes públicos da ANTT e ANTAQ \\
\hline 2315 & Regime celetista para os agentes públicos da agências reguladoras. \\
\hline 2310 & Regime celetista para os agentes públicos da agências reguladoras. \\
\hline 1668 & Regime jurídico especial e competências normativas da ANATEL. \\
\hline
\end{tabular}

A base de dados demonstra que há pouca homogeneidade nas ações movidas perante o Supremo Tribunal Federal sobre o assunto. Ao menos sete das onze agências existentes no Brasil tiveram seus poderes questionados perante o Supremo Tribunal Federal. Nesse contexto, é possível observar ao menos quatro blocos de ADIs que congregam os objetivos buscados pelos postulantes: (i) ações que contestam a própria existência do regime jurídico especial das agências reguladoras; (ii) ações que pretendem limitar a extensão dos poderes e competências das agências reguladoras; e (iii) ações que tratam especificamente sobre o regime jurídico dos agentes públicos das agências reguladoras.

\subsubsection{Contestação do regime jurídico especial das agências reguladoras}

O primeiro grupo de ações envolve casos em que foi questionada a existência de um regime jurídico especial das agências reguladoras. O leading case sobre o assunto foi a ADI no 1668, ajuizada pelo Partido Comunista do Brasil (PC do B), pelo Partido dos Trabalhadores (PT), pelo Partido Democrático Trabalhista (PDT) e pelo Partido Socialista Brasileiro (PSB) em setembro de 1997. Naquele momento, as agências reguladoras ainda estavam em fase de implementação - apenas as leis da ANEEL, da ANATEL e da ANP tinham sido editadas.

Por meio da ADI, os partidos impugnaram amplamente o regime jurídico especial das agências reguladoras. A argumentação adotada foi a seguinte: os partidos reconheceram, de início, que o art. 21, XI da Constituição Federal prevê a existência de um órgão regulador para os serviços de telecomunicações. No entanto, segundo eles, o regime jurídico disciplinado na Lei n 9.472/1997 seria manifestamente inconstitucional por violar a independência dos Poderes da República (art. $2^{\circ}, \mathrm{CRFB}$ ). Isso porque não haveria, no art. 37, inciso XIX - que disciplina o regime das autarquias - qualquer previsão de aspectos como (i) a independência administrativa; (ii) a ausência de subordinação hierárquica; (iii) a existência de mandato fixo e estabilidade de seus dirigentes; e (iv) a autonomia financeira. 
Assim, segundo os autores, a "independência administrativa" estipulada nos arts. $8^{\circ}$, $2^{\circ}$ e $9^{\circ}$ da Lei n 9.472/1997 constituiria aspecto estranho à Administração Pública brasileira, na medida em que implicaria invasão das competências privativas do Presidente da República e dos Ministros de Estado, a quem compete a direção superior da Administração Pública federal (art. 84, inciso II e art. 87, parágrafo único da CRFB). Concluem, neste cenário, que atribuir a qualquer órgão da Administração uma autonomia administrativa importaria em inevitável quebra da orientação constitucional, excluindo do Chefe da Administração Pública a possibilidade de exercer a sua função. Assim, a única leitura possível da Constituição seria aquela que permitisse o controle das agências pelos órgãos superiores da Administração Pública direta, incluindo-se a supervisão ministerial.

Por fim, outro fundamento apresentado para impugnar o modelo institucional das agências reguladoras foi a suposta inconstitucionalidade da atribuição de poderes normativos à ANATEL. Segundo a petição inicial da ADI, tal competência contrariaria o princípio da legalidade (art. 37, caput, CRFB) e o art. 25 dos Atos das Disposições Constitucionais Transitórias (ADCT) ${ }^{29-30}$

Como será identificado no subitem 4.2.3 deste artigo, o Plenário do Supremo Tribunal Federal, em menos de um ano após o ajuizamento da ADI no 1688, julgou a ação parcialmente procedente para dar a alguns dispositivos da lei interpretação conforme à CF. É possível que a posição do STF tenha sido determinante para que nenhuma outra ação impugnasse a própria existência de um regime especial das agências reguladoras. De fato, as ações apresentadas logo em seguida focaram-se em aspectos específicos de cada una das agências reguladoras, como se verá a seguir.

\subsubsection{Redução dos poderes e competências das agências reguladoras}

Ao longo do tempo, as ações relativas ao regime jurídico das agências reguladoras se sofisticaram. Em vez de contestar a própria existência das agências, os partidos políticos e o setor regulado passaram a impugnar aspectos específicos relacionados a estas instituições, seja em relação à sua própria competência, seja em relação ao alcance de seus poderes. Trata-se de um cenário de contestação do modelo de agências reguladoras não pela subversão integral de seu regime especial, mas para limitar o leque

29 Art. 25. Ficam revogados, a partir de cento e oitenta dias da promulgação da Constituição, sujeito este prazo a prorrogação por lei, todos os dispositivos legais que atribuam ou deleguem a órgão do Poder Executivo competência assinalada pela Constituição ao Congresso Nacional, especialmente no que tange a: I - ação normativa; II - alocação ou transferência de recursos de qualquer espécie.

30 Outros pontos relacionados ao regime jurídico da ANATEL também foram destacados na ADI. Segundo os autores, seria inconstitucional (i) a previsão sobre a realização de busca e apreensão; (ii) a realização de licitações para outorga de serviços mediante concessão e permissão pela ANATEL; (iii) a criação de modalidades licitatórias próprias (pregão e consulta) e a possibilidade de aprovar normas próprias de licitação e contratação. 
de ações ou instrumentos à sua disposição ${ }^{31}$. Nestes casos, embora as pretensões sejam específicas a cada uma das demandas, em grande parte delas os seus fundamentos são similares.

Veja-se a hipótese da ADI n 5906. Nela, a Associação Brasileira das Empresas de Transporte Terrestre de Passageiros - ABRATI questiona a competência da ANTT para a criação de penalidades e infrações por atos normativos infralegais. No entender da associação, seria incompatível com a Constituição Federal a delegação de poder normativo amplo e irrestrito à agência, sobretudo porque o art. 78-A da Lei no 10.233/2001 já estabeleceria um rol exaustivo sobre as possíveis sanções aplicáveis. Aponta, para tanto, o fato de que a ANTT editou a Resolução no 233/2003, "cujas disposições estabelecem diversos tipos infracionais em caráter absolutamente inovatório, cominando-Ihe as respectivas sanções, em acintosa invasão da esfera de competência atribuída exclusivamente ao Poder Legislativo pelo poder constituinte originário".

O debate levado ao STF em muito se assemelha àquele apresentado na ADI no 1668 - isto é, a legitimidade do exercício de poder normativo pelas agências reguladoras. No entanto, sobretudo por se tratar de uma ação movida pelo setor regulado, a existência per se da agência reguladora não é um ponto de estresse. Pelo contrário: de um modo geral, o modelo de agencificação é reconhecido como favorável à economia ${ }^{32}$. A estratégia do setor, portanto, é limitar o alcance dos poderes das agências (no caso, da ANTT) para garantir, em tese, uma atuação com amarras pré-estabelecidas pela lei.

A competência normativa das agências reguladoras é tema espinhoso não só do ponto de vista doutrinário, mas também político e econômico. Tanto é assim que tais poderes também foram contestados nas ADIs no 3596 (ajuizada pelo PSOL em face de poderes normativos da ANP); no 4679 (ajuizada pelo DEM contra o poder regulamentar da ANCINE no setor de produção audiovisual); no 4874 (ajuizada pela CNI contra competência normativa específica da ANVISA para proibir produtos por motivos de vigilância sanitária); e n 5372 (ajuizada pela CONUT em face da competência da ANTT para regular o transporte rodoviário coletivo regular interestadual e internacional de passageiros).

\footnotetext{
31 Conforme apontado em artigo, os órgãos de controle possuem papel relevante no enfraquecimento das agências. Uma das estratégias é justamente limitar o leque de ações ou instrumentos à disposição das instituições (cf. JORDÃO, Eduardo; RIBEIRO, Maurício Portugal. Como desestruturar uma agência reguladora em passos simples. Revista Estudos Institucionais, v. 3, n. 1, p. 180-209, ago. 2017. p. 193-195).

32 Conforme apontado por Sérgio Guerra: “O foco era criar um ambiente que privilegiasse certeza e estabilidade, de modo a atrair investimentos, sobretudo estrangeiros, e gerar salvaguardas institucionais que significassem um compromisso com a manutenção de regras e contratos de longo prazo. A competência preponderantemente técnica foi destacada nas mãos de entidades descentralizadas, demonstrando-se que a regulação de sistemas complexos e sensíveis deixava de ser assunto de Governo para ser assunto de Estado" GUERRA, Sérgio. Agências Reguladoras: da organização administrativa piramidal à governança em rede. 1. ed. Belo Horizonte: Fórum, 2012, p. 106)
} 
As ações também contestam competências executivas das agências. É o caso das ADIs no 3366 e n 3273, que pedem a declaração de inconstitucionalidade da competência da ANP para exportação do petróleo e do prazo conferido à agência para exercício do seu poder decisório (silêncio administrativo); da ADI n 4226, que impugna o poder da ANATEL para proferir decisões cautelares de busca e apreensão em processos administrativos; da ADI no 5371, que contesta o sigilo nos processos administrativos sancionadores da ANTT; e da ADI no 2658, que pretende esvaziar a competência da ANVISA para fiscalização de farmácias e drogarias.

Aliás, o caso da ADI n²658 demonstra que, por vezes, outra estratégia utilizada para enfraquecer - ou excluir - competências das agências reguladoras consiste na alegação de usurpação de competência federativa. Nesta ação, a CNC alegava que a competência fiscalizatória sobre farmácias e drogarias não poderia ser realizada pela ANVISA, mas apenas por órgãos e entidades municipais. O mesmo se deu nas recentes ações sobre o poder normativo da ANA para disciplinar diretrizes gerais no setor de saneamento básico (ADIs n 6006 e 5993). Segundo os partidos, a União - e, portanto, a ANA - não tem competência para editar normas sobre o serviço público mencionado, algo que caberia aos municípios (cf. art. 30, incisos I e IV).

Os casos da ANA apresentam peculiaridades interessantes. Há, nestas ações, um embate em favor das agências reguladoras regionais, que teriam sua independência comprometida pelas regras editadas pela ANA. Outro motivo de razão pragmática também vale ser mencionado. O Partido dos Trabalhadores defende que a criação de novas competências para a ANA implica prejuízo para as competências já desempenhadas pela agência, uma vez que seu quadro de pessoal foi qualificado apenas para as competências originais e não teriam conhecimento técnico suficiente para o exercício de novas atribuições. Assim, recomenda que a ANA se limite a regular os recursos hídricos - poder que resultou da sua criação no ano 2000 -, de modo a racionalizar sua atividade e não torna-la ineficiente.

Os casos em questão demonstram que, embora os fundamentos apresentados sejam similares, a contestação do modelo em abstrato das agências reguladoras não é um ponto de grande volume de ações. As ADls se sofisticaram ao longo do tempo para questionar aspectos específicos do regime jurídico das agências. Tanto no caso do setor regulado ou dos partidos políticos, isso pode representar uma real intenção de mera enfraquecimento da agência - ou uma estratégia para pressionar o Supremo Tribunal Federal a se manifestar contra o modelo das agências no Brasil. 


\subsubsection{Um capítulo à parte: demandas relacionadas ao regime de pessoal das agências} reguladoras

Por fim, é necessário apontar um conjunto de ações relacionadas ao regime jurídico de pessoal das agências reguladoras. No ano 2000, foi editada a Lei n 9.986/2000 que, dentre outros fatores, previa a submissão dos agentes públicos das agências reguladoras federais ao regime trabalhista. Isto é, as relações entre agências e seus empregados seriam regidas contratualmente pela Consolidação das Leis do Trabalho, e não pelo regime estatutário geral previsto para os servidores públicos federais. O objetivo da lei era conferir maior autonomia gerencial às entidades reguladoras autônomas ${ }^{33}$.

Esse regime de gestão de pessoal foi fortemente contestado ${ }^{34}$ perante o Supremo Tribunal Federal, em um primeiro momento, pelo Partido dos Trabalhadores e pelo Partido Democrático Trabalhista no bojo das ADIs no 2310 e 2315, respectivamente. Igual pleito foi formulado na ADI n²543, dessa vez para impugnar a lei de criação da ANTT e da ANTAQ (Lei no 10.233/2001). Segundo os fundamentos apresentados, o exercício de função de fiscalização, inerente à atividade precípua do Estado, pressupõe prerrogativas não agasalhadas pelo contrato de trabalho.

No mais, outras duas ações movidas perante o STF sobre o regime jurídico dos servidores das agências reguladoras têm o condão de afetar sua autonomia gerencial e política. A primeira delas, ajuizada em 2004 pelo Democratas, impugnou o art. 30 da Lei no 10.871/2004, a qual permite a contratação temporária de servidores por agências, nos termos do art. 37, IX da Constituição Federal. Já a recente ADI n 6033, ajuizada pela Associação Nacional dos Servidores Efetivos das Agências Reguladoras - ANER, pretende que sejam declaradas inconstitucionais as disposições do art. 23 e do art. 36-A da Lei n 10.871/2004 relativas à vedação ao exercício de atividades profissionais ou

\footnotetext{
33 Conforme parecer elaborado pela Comissão de Assuntos Sociais do Senado durante a tramitação do projeto de lei que lhe deu origem (PL n²549/2000): "Quando da criação das Agências Reguladoras, que foram surgindo conforme as necessidades de regulação de mercados, as leis que as instituíram acabaram por dar tratamento diferenciado à gestão dos recursos humanos. Por exercerem funções similares, essas agências necessitavam de critérios mais uniformes, quer para a nomeação dos membros de sua diretoria, quer para os requisitos mínimos exigidos para a assunção dos cargos, quer para as normas para a investidura nos empregos públicos a serem criados" (Disponível em <https://bit.ly/2WkKxQt $>$. Acesso em 19.03.2019. Grifos nossos).

34 Confira-se, a propósito, a posição de Floriano de Azevedo Marques Neto, que apresentou críticas também no campo doutrinário: "Não faz qualquer sentido que os dirigentes dos órgãos de regulação tenham estabilidade (mandatos, não indemissibilidade imotivada) e os demais agentes sejam demissíveis por ato de vontade quer dos dirigentes das agências, quer (o que é pior) da Administração central. Isso significa dizer que nas agências haverá três ordens de regimes de pessoal. Os dirigentes máximos (integrantes do órgão de direção colegiada) que terão cargos de investidura por prazo certo. Os demais agentes que xerçam funções de direção (supervisores, gerentes, superintendentes, coordenadores, etc.) que poderão ocupar cargos de confiação cuja nomeação, porém, deverá caber ao órgão de direção da agência (nunca do chefe do Executivo ou seus auxiliares). Por fim, os demais cargos que exerçam funções inerentes à atividade regulatória, os quais deverão seguir o regime estatutário, dotado de todas as garantias inerentes à carreira de servidor público ocupante de funções de estado" (MARQUES NETO, Floriano de Azevedo. Agências reguladoras independentes: fundamentos e seu regime jurídico. 1. ed. Belo Horizonte: Fórum, 2005, p. 78-79).
} 
de direções político-partidárias por servidores de agências reguladoras. O objetivo da norma é garantir a ausência de conflitos de interesses entre a atividade regulatória e as atividades exercidas por seus servidores. ${ }^{35}$ Contudo, a associação defende que tais restrições violam a liberdade de profissão, a liberdade partidária, o pluralismo político, o direito de reunião, a liberdade de associação e a liberdade de expressão e manifestação do pensamento. ${ }^{36}$

\subsection{Quando postulam?}

A terceira pergunta a ser respondida por este artigo está relacionada com o momento em que os agentes litigam perante o Supremo Tribunal Federal para questionar o regime jurídico das agências reguladoras. Nesse ponto, confira-se a linha do tempo quanto às ações ajuizadas no período entre 1997 e 2018:

O gráfico acima não representa nenhum indicativo relevante sobre um período de maior contestação de leis sobre agências reguladoras, tampouco uma tendência de crescimento ou decréscimo do volume de ADIs ao longo do tempo. O ano de 2018 é fundamental para essa compreensão: nada menos que quatro ações foram ajuizadas perante o Supremo Tribunal Federal, o que demonstra que um tema aparentemente adormecido retornou a ser objeto de debate perante a Corte Superior.

No entanto, caso avaliada a relação entre a data em que a lei impugnada foi editada e a data de ajuizamento da ação, é possível identificar padrões mais evidentes. Quanto a este ponto, a tabela a seguir estipula dados temporais sobre as ADIs identificadas na pesquisa:

\footnotetext{
35 Segundo a manifestação da Advocacia Geral da União apresentada naquele feito, "a providência jurisdicional postulada pela entidade autora, consistente na determinação de suspensão dos efeitos das disposições hostilizadas, é que se reveste da potencialidade de minar o princípio da moralidade e a tentativa de salvaguardar as agências reguladoras da captura". Acrescenta, ainda, que "as normas atacadas atendem, também, ao requisito da adequação (subprincípio da proporcionalidade), pois criam vedações aptas a atingir o objetivo buscado, qual seja, o desempenho isento, transparente e adequado de atividades relevantes para o bem do interesse público nelas consubstanciado". Mais informações em Jornal do Brasil. "AGU se opõe a servidores de agências reguladoras dirigirem empresas". Disponível em: <https://bit.ly/2WhUo9J >. Acesso em 19.03.2019.

36 Segundo a petição inicial da ADI, a intenção dos servidores é que se possa "autorizar que certas profissões sejam exercidas pelo servidor quando houver compatibilidade de horários, e que não tenha conflito de interesses com a atividade regulada, a exemplo de servidor que tenha interesse de apresentar-se em shows de música nos finais de semana e receber uma contraprestação por isso; do servidor que tenha interesse de exercer a atividade de mecânico e receber uma contraprestação por isso; ou atividade de dentista; ou instrutor de paraquedismo, ou chefe de cozinha, etc".
} 


\begin{tabular}{|c|c|c|c|c|c|}
\hline Número & Lei & Publicação & Distribuição & $\begin{array}{l}\text { Rea- } \\
\text { ção } \\
\text { (dias) }\end{array}$ & $\begin{array}{l}\text { Rea- } \\
\text { ção } \\
\text { (anos) }\end{array}$ \\
\hline 3240 & Lei no $10.871 / 2004$ & $20 / 05 / 2004$ & $25 / 06 / 2004$ & 36 & 0,09 \\
\hline 2310 & Lei n 9.986/2000 & $18 / 07 / 2000$ & $30 / 08 / 2000$ & 43 & 0,11 \\
\hline 5993 & $M P n^{\circ} 844 / 2018$ & 06/07/2018 & $21 / 08 / 2018$ & 46 & 0,12 \\
\hline 1668 & Lei n 9472/1997. & 16/07/1997 & 09/09/1997 & 55 & 0,15 \\
\hline 6006 & $M P n^{\circ} 844 / 2018$ & $06 / 07 / 2018$ & $04 / 09 / 2018$ & 60 & 0,16 \\
\hline 2315 & Lei n॰ 9.986/2000 & $18 / 07 / 2000$ & $19 / 09 / 2000$ & 63 & 0,17 \\
\hline 4679 & Lei $n^{\circ} 12.485 / 2011$ & $12 / 09 / 2011$ & $18 / 11 / 2011$ & 67 & 0,18 \\
\hline 2543 & Lei no 10.233/2001 & 05/06/2001 & $16 / 10 / 2001$ & 133 & 0,36 \\
\hline 2658 & $M P n^{\circ} 2190-34 / 2001$ & $23 / 08 / 2001$ & $28 / 05 / 2002$ & 278 & 0,76 \\
\hline 5372 & $\begin{array}{c}\text { Lei } n^{\circ} 12.996 / 2014 \text {; Lei } \\
n^{\circ} 10.233 / 2001\end{array}$ & $18 / 06 / 2014$ & $28 / 08 / 2015$ & 436 & 1,19 \\
\hline 3273 & Lei n॰ 9478/1997 & 06/08/1997 & 09/08/2004 & 2560 & 7,01 \\
\hline 3366 & Lei n 9.478/1997 & 06/08/1997 & $09 / 12 / 2004$ & 2682 & 7,34 \\
\hline 3596 & Lei $n^{\circ} 9.478 / 1997$ & 06/08/1997 & $11 / 10 / 2005$ & 2988 & 8,18 \\
\hline 4226 & $\begin{array}{l}\text { Lei n 9.472/1997; Lei } \\
\quad n^{\circ} 10.871 / 2004\end{array}$ & 16/07/1997 & $14 / 04 / 2009$ & 4290 & 11,75 \\
\hline 4874 & Lei $n^{\circ}$ 9.782/1999 & 26/01/1999 & $06 / 11 / 2012$ & 5033 & 13,7 \\
\hline 5371 & Lei no 10.233/2001 & 05/06/2001 & $28 / 08 / 2015$ & 5197 & 14,23 \\
\hline 6033 & Lei $10.871 / 2004$ & $20 / 05 / 2004$ & $15 / 10 / 2018$ & 5261 & 14,41 \\
\hline 5906 & Lei no 10.233/2001 & $05 / 06 / 2001$ & 05/03/2018 & 6117 & 16,75 \\
\hline
\end{tabular}

As informações acima demonstram que parte das ações ajuizadas em face de leis instituidoras de competências ou disciplinadoras do regime jurídico das agências reguladoras foram impugnada em menos de três meses após a sua publicação, período relativamente curto para o ajuizamento de ADIs perante o Supremo Tribunal Federal. Um dado interessante sobre esse ponto é que, em todos esses casos, o autor da ação é um partido político. 


\begin{tabular}{|c|c|c|}
\hline Número & Tempo de reação (dias) & Autor \\
\hline 3240 & 36 & DEM \\
\hline 2310 & 43 & PT \\
\hline 5993 & 46 & PSB \\
\hline 1668 & 55 & PC do B, PT, PDT e PSB \\
\hline 6006 & 60 & PDT \\
\hline 2315 & 63 & PDT \\
\hline 4679 & 67 & DEM \\
\hline
\end{tabular}

No mais, segundo os dados obtidos na pesquisa, há ainda um número relevante de ações movidas perante o Supremo Tribunal Federal em que leis que disciplinam o regime jurídico das agências reguladoras são impugnadas após ultrapassado tempo considerável entre a edição do ato impugnado e o ajuizamento da ADI.

Em determinados casos, os agentes regulados o fazem ainda em tempo intermediário (superior a noventa dias, mas inferior a um ano). Contudo, em outros, determinadas ações são ajuizadas em períodos que variam entre sete e dezesseis anos, o que evidencia um tempo de reação consideravelmente longo.

\begin{tabular}{|c|c|c|}
\hline Número & Tempo de reação & Autor \\
\hline 2543 & 133 & ABER \\
\hline 2658 & 278 & CNC \\
\hline 5372 & 436 & CONUT \\
\hline 3273 & 2560 & PDT \\
\hline 3366 & 2682 & PSOL \\
\hline 3596 & 2988 & ABRAMULTI \\
\hline 4226 & 4290 & CNI \\
\hline 4874 & 5033 & PGR \\
\hline 5371 & 5197 & ANER \\
\hline 6033 & 5261 & ABRATI \\
\hline 5906 & 6117 & \\
\hline
\end{tabular}

Um exemplo disso é a ADI n 5372, que foi impetrada pela Confederação Nacional dos Usuários de Transportes Coletivos Rodoviário, Ferroviário, Hidroviário e Aéreo (Conut), pretendendo obter a declaração de inconstitucionalidade do artigo 14, III, "j" da Lei 10.233/2001. Referido dispositivo havia sido alterado pelo art. $3^{\circ}$ da Lei 12.996/2014. Segundo a requerente da ação, a norma introduziu disciplina inconstitucional de 
delegação dos serviços públicos, alterando o regime de exploração de transportes coletivos interestaduais e internacionais para o de autorização, o que usurparia competência privativa do Chefe do Poder Executivo (art. 84, inciso IV da CRFB).

Segundo a legislação impugnada, a regulamentação desse procedimento de autorização dos serviços de transporte seria feita por meio de ato normativo expedido pela ANTT. Nesse sentido, a agência editou a Resolução 4.770/2015, que disciplinou a matéria. O que é interessante avaliar, neste caso, é o possível impulsionamento causado pelo aludida resolução. Isso porque o protocolo da ADI foi realizado no dia 20 de agosto de 2015, pouco menos de um mês após a edição do ato normativo (publicado no dia 25 de julho de 2015). Isso demonstra que a reação, embora relativamente lenta em relação à Lei no 12.996/2014 - cerca de mais de um ano -, foi rápida em relação ao seu ato regulamentador.

Trata-se de uma evidência de que atos concretos das agências reguladoras podem levar a um movimento de retomada da contestação de seus poderes em abstrato pelos agentes regulados afetados por tais decisões regulatórias. Por certo, essa premissa não será verdadeira em todos os casos, mas pode ser um elemento relevante para a compreensão de uma fase menos imediata de contestação do modelo das agências reguladoras perante o Supremo Tribunal Federal.

Essa premissa também é identificada, e.g., nas ADIs no 3596, 3366 e 3273, ajuizadas por partidos políticos e pelo Governador do Estado do Paraná em face de dispositivos da Lei no 9.478/1997, que criou a Agência Nacional do Petróleo. Nestas ações, o tempo de reação também pode ser justificado por elementos contextuais.

Isso se torna perceptível a partir da ADI no 3273 . A ação foi formulada com pedido cautelar com o objetivo de suspender dispositivos da Lei do Petróleo. O periculum in mora era fundamentado na ocorrência da $6^{a}$ Rodada de Licitações das áreas produtoras de petróleo e gás natural, em que a Bacia de Santos, próxima ao litoral do Estado do Paraná, faria parte do certame. Foram justamente tais circunstâncias, aliás, que levaram o Supremo Tribunal Federal a reconhecer a pertinência temática do Governador para o ajuizamento da ADI.

O mesmo se diga em relação à ADI no 3596, ajuizada pelo PSOL. Segundo o partido, o contexto do ajuizamento da ação se deu com a publicação da 7a Rodada de Licitações de Bacias Petrolíferas pela ANP. O pedido cautelar do partido expõe o verdadeiro motivo para o ajuizamento da ADI: "Não se trata de periculum com o advento da lei, mas com o uso concreto que dela foi dado, com a utilização nefasta de a tribuição exclusiva delegada pelo legislador ordinário a uma autarquia, evidenciando efetiva perda definitiva do subsolo nacional". Igual circunstância ocorreu no bojo da ADI n 3273, que levou, 
inclusive, à suspensão da $6^{a}$ Rodada de Licitações pelo Ministro relator Ayres Britto. ${ }^{37}$ Ou seja: para limitar uma atuação específica da agência, o partido buscou no Supremo Tribunal Federal um meio para conseguir, de forma célere, um provimento geral que limitasse de forma ampla os poderes gerais da ANP.

A ADI n 4.874 talvez seja ainda mais evidente em relação a esta hipótese. Ajuizada mais de treze anos após a edição da Lei n 9.781/1999, a ação questionava o poder regulatório da ANVISA para proibir a produção de produtos por meio de atos gerais e abstratos, ante a competência prevista no seu art. 70, inciso XV. A relatora do caso, Ministra Rosa Weber, destacou em seu relatório que "o pano de fundo da discussão [foi] $a$ iniciativa da ANVISA de proibir a importação e a comercialização no país de produtos fumígenos derivados do tabaco que contenham as substâncias ou compostos que define como aditivos". Tanto é assim que o próprio ato regulamentar mencionado - a Resolução da Diretoria Colegiada no 14, editada em março de 2012 - foi objeto explícito de impugnação por meio da ação direta, ajuizada em agosto do mesmo ano.

\subsection{Conclusões parciais em relação aos postulantes}

Foi possível notar, a partir dos dados observados, que a ADI é uma ferramenta para um debate essencialmente político sobre as agências reguladoras, sendo o Supremo Tribunal Federal um foro relevante para deflagrar tal discussão de forma célere e imediata. Ainda sob a ótica dos postulantes, foi possível notar que o setor regulado, embora não seja necessariamente contrário ao modelo das agências reguladoras no Brasil, vem tentando diminuir o alcance de seu poder em casos específicos, muitas vezes diante de algum elemento contextual que funciona como gatilho desta pretensão.

\section{O DEBATE SOBRE AS AGÊNCIAS REGULADORAS SOB A ÓTICA DO PROCESSO DECISÓRIO DO STF.}

Conforme apresentado anteriormente, o item 4 deste artigo se destinará a analisar os dados relacionados à atuação do Supremo Tribunal Federal nas ações em que foram impugnadas leis que disciplinam o regime jurídico das agências reguladoras. Mais especificamente, os subitens a seguir avaliarão, com base nas mesmas premissas do item anterior (i) quais processos foram julgados até o momento, o tempo de tramitação dos feitos e os dados sobre o momento em que houve alguma decisão relacionada às leis das agências reguladoras (quando decidem); (ii) quais assuntos foram decididos até então pelo STF, incluindo-se o posicionamento institucional da Corte (o que e como

37 A medida foi posteriormente revogada pelo Min. Nelson Jobim. Confira-se em Consultor Jurídico. "Supremo mantém leilão da Agência Nacional de Petróleo". Disponível em: <https://bit.ly/2VM0yud $>$. Acesso em 19.03.2019. 
decidem); (i) os dados gerais sobre os posicionamento individuais dos Ministros, decisões liminares e decisões de mérito, quando existentes (quem e como decidem).

\subsection{Quando decidem?}

O primeiro passo é identificar quando os processos relacionados às leis que disciplinam o regime jurídico das agências reguladoras brasileiras. Tal tópico envolve a própria análise sobre quais processos foram julgados (tanto monocraticamente como por decisão colegiada), qual o tempo de deliberação das demandas já julgadas e em quanto tempo eles tramitam perante a Corte.

\subsubsection{Casos julgados e linha do tempo}

Em relação aos processos que já foram objeto de deliberação (provisória ou definitiva), foi identificado um total de 10 ações (pouco mais da metade), sendo que 5 delas foram extintas por questões processuais (não conhecimento da ação) ou fáticas (perda do objeto por revogação da norma impugnada). Confira-se a tabela abaixo com a linha do tempo sobre os julgamentos:

\begin{tabular}{|c|c|c|c|}
\hline Número & $\begin{array}{l}\text { Agência Regu- } \\
\text { ladora }\end{array}$ & Resultado provisório ou final & Data da decisão \\
\hline 4874 & ANVISA & $\begin{array}{l}\text { Liminar deferida | Improceden- } \\
\text { te }^{38}\end{array}$ & $\begin{array}{c}17 / 09 / 2013 \mid \\
01 / 02 / 2018\end{array}$ \\
\hline 4679 & ANCINE & Procedência parcial| ${ }^{39}$ & $08 / 11 / 2017$ \\
\hline 5372 & ANTT & Não conhecimento da ADI & $17 / 10 / 2017$ \\
\hline 3240 & Todas & Perda do objeto & $14 / 10 / 2016$ \\
\hline 3366 & ANP & Improcedente & $16 / 03 / 2005$ \\
\hline 3273 & ANP & Improcedente & $16 / 03 / 2005$ \\
\hline 2315 & Todas & Perda do objeto & $09 / 12 / 2004$ \\
\hline 2310 & Todas & $\begin{array}{c}\text { Liminar deferida | Perda do } \\
\text { objeto }\end{array}$ & $\begin{array}{c}19 / 12 / 2000 \mid \\
09 / 12 / 2004\end{array}$ \\
\hline 2543 & ANTT e ANTAQ & Não conhecimento da ADI & $05 / 11 / 2001$ \\
\hline 1668 & ANATEL & Liminar parcialmente deferida & $20 / 08 / 1998$ \\
\hline
\end{tabular}

38 O acórdão lavrado no bojo da ADI n 4874 foi objeto de embargos de declaração, ainda não apreciados pelo Supremo Tribunal Federal.

39 O dispositivo declarado inconstitucional no bojo da ADI n॰ 4679 não se relaciona ao tema deste artigo, isto é, ele se relacionado ao marco regulatório do setor audiovisual, mas não tem relação com o regime jurídico da ANCINE. 
A linha do tempo de tais decisões demonstra que um período de quase uma década separa blocos de períodos em que o modelo institucional das agências reguladoras esteve em debate no Supremo Tribunal Federal: o primeiro, entre 1998 e 2005; e o segundo, entre 2013 e 2018. O primeiro deles, como se viu, foi marcado por um primeiro período de contestação das agências reguladoras, em que houve uma série de ações ajuizadas por partidos políticos em face das leis criadoras de tais entidades (e.g., ADI no 1668) ou que definiam o seu regime jurídico como um todo (e.g., ADI n²310). Já o segundo bloco de decisões se dá num momento em que o modelo institucional das agências reguladoras já se encontra consolidado no Brasil, representando uma etapa de sua reafirmação por um órgão colegiado composto por diferentes membros ${ }^{40}$. Como se verá no item 4.2, isso levou a uma visão mais sofisticada sobre as agências reguladoras e os parâmetros para sua atuação.

Além disso, se atentarmos aos casos em que houve julgamento colegiado, poucas foram as manifestações do Supremo Tribunal Federal ao longo destes anos. De fato, apenas nos anos de 2005, 2017 e 2018 o plenário do STF se manifestou sobre o regime jurídico, respectivamente, da ANP (ADI ns 3273 e 3266), da ANCINE (ADI n 4679) e da ANVISA (ADI n० 4874) de forma definitiva. Adiciona-se, ainda, a ADI n 1668, em que o regime jurídico da ANATEL foi objeto de julgamento do plenário da Corte em sede de medida cautelar. Isso demonstra que o julgamento da constitucionalidade de leis que tratam sobre o regime jurídico das agências reguladoras no Brasil não é uma constante, revelando um comportamento casuístico do STF sobre o assunto.

\subsubsection{Tempo de deliberação}

No reduzido espaço amostral de decisões tomadas pelo plenário do Supremo Tribunal Federal, há um dado que revela uma constante em relação a todos os casos: a necessidade de mais de uma sessão da Corte para deliberação. De fato, observando a data entre o início e o fim do julgamento das cinco ações apreciadas pelo colegiado, conclui-se que o debate sobre o regime jurídico das agências reguladoras demanda um tempo de debate acima da média, por motivos como pedidos de vista (como no caso das ADIs nos 3273, 3366 e 4679), a forma de deliberação (na ADI n 1668, o Ministro Marco Aurélio, então relator, optou por fracionar o voto por grupos de dispositivos impugnados) e um número elevado de sustentações orais, tal como ocorreu no caso da ADI n० 4874.

40 Veja que, em 2005, o órgão colegiado era composto pelos Ministros Ayres Britto, Eros Grau, Nelson Jobim, Marco Aurélio, Ellen Gracie, Joaquim Barbosa, Celso de Mello, Sepúlveda Pertence, Carlos Velloso, Gilmar Mendes e Cezar Peluso. Em 2017, por sua vez, a análise do colegiado foi composta pelos Ministros Luiz Fux, Edson Fachin, Roberto Barroso, Teori Zavascki (sucedido por Alexandre de Moraes), Rosa Weber, Dias Toffoli, Ricardo Lewandowski, Carmen Lúcia, Celso de Mello, Gilmar Mendes e Marco Aurélio. Como é possível notar, apenas os Ministros Marco Aurélio, Gilmar Mendes e Celso de Mello compuseram o colegiado em ambas as oportunidades. 


\begin{tabular}{|c|c|c|c|c|c|c|}
\hline Número & $\begin{array}{c}\text { Agência } \\
\text { Regula- } \\
\text { dora }\end{array}$ & $\begin{array}{c}\text { Início do } \\
\text { julgamento }\end{array}$ & $\begin{array}{c}\text { Fim do jul- } \\
\text { gamento }\end{array}$ & $\begin{array}{c}\text { Tempo } \\
\text { (dias) }\end{array}$ & $\begin{array}{c}\text { Tempo } \\
\text { (anos) }\end{array}$ & Sessões \\
\hline 4874 & ANVISA & $09 / 11 / 2017$ & $01 / 02 / 2018$ & 84 & 0,23 & 2 \\
\hline 4679 & ANCINE & $25 / 06 / 2015$ & $08 / 11 / 2017$ & 867 & 2,37 & 3 \\
\hline 3273 e & ANP & $16 / 09 / 2004$ & $16 / 03 / 2005$ & 181 & 0,49 & 4 \\
\hline 3366 & ANATEL & $01 / 10 / 1997$ & $20 / 08 / 1998$ & 323 & 0,88 & 3 \\
\hline
\end{tabular}

\subsubsection{Tempo de tramitação}

Em relação ao tempo de tramitação, não é possível apontar nenhuma tendência específica do STF. Entre os procedimentos que ainda não foram julgados em seu mérito, há casos que aguardam sua análise pelo colegiado há mais de vinte anos, havendo um elevado percentual de contingente de ações ainda não julgadas em relação ao número total do espaço amostral delimitado na pesquisa.

\begin{tabular}{|c|c|c|c|}
\hline ADI & Ajuizamento & Tramitação (dias) & Tramitação (anos) $^{\mathbf{4 1}}$ \\
\hline 6033 & $15 / 10 / 2018$ & 77 & 0,21 \\
\hline 6006 & $04 / 09 / 2018$ & 118 & 0,32 \\
\hline 5993 & $21 / 08 / 2018$ & 132 & 0,36 \\
\hline 5906 & $05 / 03 / 2018$ & 301 & 0,82 \\
\hline 3071 & $28 / 08 / 2015$ & 1221 & 3,34 \\
\hline 4226 & $14 / 04 / 2009$ & 3548 & 9,72 \\
\hline 3596 & $11 / 10 / 2005$ & 4829 & 13,23 \\
\hline 2658 & $28 / 05 / 2002$ & 6061 & 16,6 \\
\hline 1668 & $09 / 09 / 1997$ & 7783 & $21,32^{42}$ \\
\hline
\end{tabular}

Quanto aos casos que já tiveram julgamento final (de mérito ou extinto por razões processuais), também não é possível vislumbrar nenhuma orientação específica a partir da prática do Supremo Tribunal Federal. Os quatro casos em que houve decisão definitiva se dividem entre aqueles que foram julgados ora de forma muito célere (tal como os casos relativos à ANP - ADIs n 3273 e n 3366), ora com um tempo considerável para a apreciação final pelo colegiado (mais de cinco anos), tal como identificado nas ADIs n 4874 e 4679.

41 Considerando-se até o dia 31/12/2018.

42 Embora o tempo de tramitação da ADI no 1668 seja o mais longo entre as ações identificadas, o deferimento da medida cautelar pelo Plenário do STF foi relativamente célere: entre a data do ajuizamento (09/09/1997) e a data do julgamento da liminar (20/08/1998), há apenas 345 dias, menos de um ano. 


\begin{tabular}{|c|c|c|c|c|}
\hline ADI & Ajuizamento & Julgamento & Tempo (dias) & Tempo (anos) \\
\hline 2543 & $16 / 10 / 2001$ & $05 / 11 / 2001$ & 20 & 0,05 \\
\hline 3366 & $09 / 12 / 2004$ & $16 / 03 / 2005$ & 97 & 0,26 \\
\hline 3273 & $09 / 08 / 2004$ & $16 / 03 / 2005$ & 219 & 0,6 \\
\hline 5372 & $28 / 08 / 2015$ & $17 / 10 / 2017$ & 781 & 2,13 \\
\hline 2315 & $19 / 09 / 2000$ & $09 / 12 / 2004$ & 1542 & 4,22 \\
\hline 2310 & $30 / 08 / 2000$ & $09 / 12 / 2004$ & 1562 & 4,27 \\
\hline 4874 & $06 / 11 / 2012$ & $01 / 02 / 2018$ & 1913 & 5,24 \\
\hline 4679 & $18 / 11 / 2011$ & $08 / 11 / 2017$ & 2182 & 5,97 \\
\hline 3240 & $25 / 06 / 2004$ & $14 / 10 / 2016$ & 4494 & 12,35 \\
\hline
\end{tabular}

\subsection{O que e como decidem?}

Avaliado o fator tempo sobre os julgados do STF, passa-se à análise sobre a segunda questão a ser analisada em relação ao Supremo Tribunal Federal: os assuntos tratados pela Corte em relação às agências reguladoras e o posicionamento adotado a partir dos tópicos identificados.

Uma nota preliminar, contudo, é necessária. A tarefa de definir o posicionamento institucional do STF não é fácil. Isso porque o método de deliberação colegiada do Supremo Tribunal Federal não é construído de forma que a corte tome decisões com base em fundamentos uniformes, cabendo a cada Ministro apresentar as razões pelas quais entende que um processo deve ser julgado procedente ou não. Isso significa que o resultado final e a ementa apresentada pelo relator não necessariamente refletem o entendimento exposto por todos os membros do tribunal, mesmo em casos nos quais os resultados são unânimes. Esse fenômeno é conhecido como "onze ilhas", conforme expressão cunhada por Virgílio Afonso da Silva ${ }^{43}$. A despeito de tais dificuldades metodológicas, os subtópicos a seguir demonstrarão as decisões definitivas do Supremo Tribunal Federal sobre a matéria do ponto de vista institucional, ainda que o posicionamento individual dos Ministros (tema que será explorado no item a seguir) tenha relevância para tanto.

\subsubsection{O modelo institucional das agências reguladoras}

De um modo geral, é possível afirmar que o STF considera, em abstrato, o modelo das agências reguladoras compatível com a Constituição Federal. A concepção do tribunal sobre o assunto, no entanto, é cambiante ao longo do tempo. Em um primeiro momento, as agências reguladoras foram consideradas constitucionais porque a dita

43 SILVA, Virgílio Afonso da. Deciding without deliberating. I.CON, v. 11, n. 3, p. 557-584, 2011. 
independência administrativa não afastaria a supervisão ministerial e o controle da entidade pelo chefe do Poder Executivo. Em um segundo momento, contudo, a autonomia das agências reguladoras é reforçada pelo posicionamento da Corte, que reconhece sua importância para a tomada de decisões técnicas, céleres e insuladas do processo político. Tais entendimentos, a propósito, coincidem com os dois blocos de conjuntos de decisões identificados na linha do tempo no subitem 4.1.1.

A primeira ação em que o Supremo Tribunal Federal se debruçou sobre o assunto foi a $A D I$ n' 1668, que tinha por objetivo impugnar o regime jurídico especial da Agência Nacional de Telecomunicações (ANATEL). Em relação à matéria examinada isto é, a contestação em abstrato do modelo das agências reguladoras, o autor da ADI havia postulado a declaração de inconstitucionalidade dos arts. $8^{\circ}, \S 2^{\circ}$ e $9^{\circ}$ da Lei no 9.742/1997, que previam a criação da agência reguladora e conferiam a ela a "independência administrativa" própria destas instituições. Segundo o entendimento assentado pelo Plenário entre 1997 e 1998, o Decreto-lei n 200/1967 previa há muito a existência de autarquias, entidades autônomas em relação a sua personalidade jurídica, e modo que não haveria qualquer inconstitucionalidade na criação da ANATEL em abstrato. Para tanto, afirmou que o regime especial "longe está de revelar a existência de uma entidade soberana, afastada do controle pertinente". Portanto, o modelo institucional da ANATEL só foi considerado constitucional porque a tutela administrativa exercida pelo Ministério das Comunicações e pelo Presidência da República subsistiriam em relação àquela entidade da Administração Pública indireta. ${ }^{44}$

O mesmo se deu em relação à Agência Nacional do Petróleo. Nas ADls n 3273 e 3366, julgadas entre os anos de 2004 e 2005, o entendimento prevalecente da maioria do Plenário do STF assentou a constitucionalidade do art. 60 da Lei n 9.478/1997, que conferia à ANP a competência para autorizar a exportação de petróleo no Brasil. O grande embate sobre a questão condizia na violação ou não à soberania nacional com a atribuição de tal competência a uma entidade administrativa independente (e não ao Poder Executivo central). Mais uma vez, um dos fundamentos adotados para afastar a inconstitucionalidade do dispositivo foi a circunstância de que a independência da agência era limitada. Dito de outro modo, não haveria nenhum comprometimento à soberania nacional, uma vez que, para exportar petróleo, a agência reguladora deveria observar as políticas aprovadas pelo Presidente da República, propostas pelo Conselho Nacional de Política Energética - CNPE, conforme disposto no art. $4^{\circ}$ da Lei n. 8.176/1991. Ainda na visão prevalecente do Plenário, a ANP, enquanto autarquia, estaria submetida à direção superior do Presidente da República, nos termos do art. 84, inciso II da Constituição Federal, motivo pelo qual o dispositivo impugnado seria

44 Embora no acórdão o relator tenha mencionado expressamente o termo "indeferimento do pedido", o pronunciamento da decisão final foi de que o Plenário, em votação unânime, não conheceu a ADI em relação aos arts. $8^{\circ}$ e $9^{\circ}$ da Lei n 9.472/1997. 
constitucional. Significa dizer que, para os fins desta pesquisa, o resultado final das ADIs é uma contradição em seus próprios termos: a manutenção da competência da ANP é fruto da ausência de autonomia reforçada da agência.

O segundo bloco de decisões, contudo, revela uma defesa mais sólida do modelo das agências reguladoras. Na ADI n 4679, julgada entre os anos de 2015 e 2017, o Supremo Tribunal Federal validou competências atribuídas à ANCINE para a regulação do setor audiovisual nacional, reconhecendo a importância dos desenhos institucionais de tais entidades. $\mathrm{O}$ acórdão do caso expõe extensos votos em que são abordadas questões como (i) o conhecimento técnico e especializado das agências reguladoras; e (ii) a necessidade de respostas mais rápidas do que as propiciadas pelo naturalmente moroso processo legislativo formal. Nesse contexto, (iii) as agências reguladoras, reconhecidamente dotadas de autonomia reforçada e concentradoras de funções públicas normalmente distribuídas entre Poderes do Estado, (iv) são voltadas ao desenvolvimento de normas setoriais aptas a, com autonomia e agilidade, regular a complexa e dinâmica realidade social subjacente.

O mesmo se deu na $A D I$ n 4874 , ajuizada com o objetivo exclusivo de discutir a extensão do poder normativo da ANVISA. Naquela oportunidade, reconheceu-se que as agências reguladoras representam inegável aperfeiçoamento da arquitetura institucional do Estado de Direito contemporâneo no sentido do oferecimento de uma resposta da Administração Pública para fazer frente à complexidade das relações sociais verificadas na modernidades. Sua importância também é destacada ante a exigência de agilidade e flexibilidade para lidar com decisões de natureza técnica, o que levou à emergência destas estruturas administrativas relativamente autônomas e independentes.

Como é possível notar, o discurso de legitimação das agências nos votos apresentados nestes casos revela uma variação do Supremo Tribunal Federal no enfrentamento do assunto. Se antes as agências eram constitucionais porque estavam sujeitas à tutela do Poder Executivo, a concepção atual é que seu modelo institucional é relevante dentro de uma nova concepção de separação de poderes em que decisões de caráter técnico e isentas são essenciais para a promoção de finalidades públicas específicas.

\subsubsection{O poder normativo das agências reguladoras}

O principal assunto relativo à independência das agências reguladoras nas decisões proferidas pelo STF está no debate sobre a abrangência e extensão do poder normativo de tais entidades.

A função normativa da ANATEL foi objeto de intensa controvérsia entre os membros do STF no bojo da ADI no 1668. A maioria do STF adotou a orientação de que o poder de editar normas gerais e abstratas era possível, desde que em caráter regulamentar, 
subordinada à legislação e a eventuais atos normativos da Presidência da República. Conforme assentado pelo Plenário, a atuação normativa das agências reguladoras não poderia subtrair do agente político a competência reguladora da lei de telecomunicações. Foi nesse sentido que foi dada interpretação conforme à Constituição em relação aos dispositivos impugnados para fixar a tese de que os atos normativos da agências reguladoras deveriam necessariamente observar a lei (preferência da lei sobre os atos regulatórios) - orientação seguida pela maioria dos julgadores ${ }^{45}$.

O Supremo Tribunal Federal voltou a se pronunciar acerca do regime jurídico das agências reguladoras apenas em 2015, em julgamento que durou mais que dois anos. Tratava-se da ADI no 4679, que tinha como objetivo ver declarada inconstitucional a Lei no 12.485/2011 na parte em que reconhecia diversas competências da ANCINE para regular o setor audiovisual de acesso condicionado (a antiga TV a cabo).

Na oportunidade, o STF também votou a favor da competência normativa da ANCINE. Mas sua concepção sobre o princípio da legalidade em relação às agências reguladoras foi sensivelmente distinta. Segundo o tribunal, a Constituição chancela a atribuição de poderes normativos ao Poder Executivo, desde que pautada por princípios inteligíveis (intelligible principles) ${ }^{46}$ capazes de permitir o controle legislativo e judicial sobre os atos da Administração. Daí porque o importante não era condicionar a atuação da ANCINE estritamente aos comandos legais; mas sim avaliar se sua lei de criação (Medida Provisória n².228-1/2001) e se a lei que disciplina o serviço de acesso condicionado (art. $3^{\circ}$ da Lei $n^{\circ} 12.485 / 2011$ ) seriam suficientes para lhe atribuir poderes normativos. Apenas se tais normas legais fossem demasiadamente amplas é que se evidenciaria a inconstitucionalidade do poder normativo da agência. No fim, concluiu-se que a técnica legislativa empregada na legislação era constitucional, na medida em que atendia à contemporânea noção de Estado regulador, em que o papel da lei em sentido formal é apenas definir as metas principais e os contornos da atividade do órgão regulador, cometendo-lhe margem relativamente ampla de atuação, mas condicionada aos espaços deixados em aberto pela legislação.

Igual entendimento foi firmado no âmbito da ADI no 4874. No que concerne especificamente ao poder normativo da ANVISA, o Supremo Tribunal Federal, por

\footnotetext{
45 O debate, contudo, não foi livre de controvérsias. Neste ponto, destaca-se a posição do Ministro Nelson Jobim que, desde o início do julgamento, apresentou divergência quanto aos pleitos formulados pelos autores da ação. Em relação ao poder normativo, o Ministro apontava que a técnica da interpretação conforme era desnecessária - o que foi corroborado pelo Ministro Moreira Alves ao afirmar que "não há necessidade de interpretação conforme para dizer o óbvio" (Voto do Ministro Moreira Alves, p. 164).

46 A denominada doutrina dos princípios inteligíveis (intelligible principles) é importada dos Estados Unidos. Segundo ela, é possível que o legislador transfira capacidades normativas à Administração Pública, desde que defina standards suficientes para o exercício deste poder - isto é, princípios inteligíveis. Conforme apontado por André Cyrino, tal doutrina foi acolhida pela Suprema Corte americana no caso Whitman v. American Trucking Associations, Inc., julgado em 2001. Sobre o tema, v. CYRINO, André. Delegações legislativas, regulamentos e Administração Pública. Belo Horizonte: Fórum, 2018, p. 77/97
} 
maioria, entendeu que a legislação setorial de vigilância sanitária possuía elementos suficientes para a aferição da legitimidade do poder normativo da agência. No entanto, por se tratar da primeira ação em que o Supremo se debruçou exclusivamente sobre o tema da edição de normas por entidades reguladoras independentes, os parâmetros apresentados pelo STF relevam uma sofisticação ímpar sobre o tema.

De modo sintético, é possível afirmar que a orientação geral do colegiado dirigiu-se no sentido de que, para que o exercício de competências normativas pelas agências reguladoras) seja considerada legítima, (i) não poderá envolver matérias sujeitas, por decisão constitucional, à reserva de lei, e (ii) tal competência há de ser acompanhada de parâmetros mínimos e claros, que, de modo enfático, limitem a atuação da agência reguladora, e permitam a fiscalização dos seus atos (reiterando-se a tese dos princípios inteligíveis, ou da tipificação mínima); e que (iii) é possível o controle a posteriori dos atos das agências reguladoras, ainda que seja recomendável a adoção de uma postura deferente do Poder Judiciário em relação às suas decisões técnicas, cabendo ao Judiciário avaliar apenas se a solução a que chegou a agência foi devidamente fundamentada e se tem lastro em interpretação da lei razoável e compatível com a Constituição

Como é possível notar, os standards adotados pelo STF na ADI n 1668 e aqueles estipulados nas ADIs $n^{\circ 5} 4679$ e 4874 foram sensivelmente distintos. Na fase em que o modelo das agências reguladoras ainda era posto em cheque, cabia ao STF ser cauteloso e permitir que o exercício do poder normativo pelas agências reguladoras não fugissem abruptamente da concepção majoritária da época sobre o princípio da legalidade. O mundo dos fatos, desde então, demonstrou que o exercício de competências administrativas normativas é um dado inevitável para a realidade contemporânea e complexa da Administração Pública. Por isso que a fase de consolidação do modelo das agências reguladoras pela jurisprudência do STF vem acompanhada de uma nova visão, em que a Corte deixa de se preocupar se é possível a edição de normas, voltando-se a questionar como essa competência deve ser exercida. ${ }^{47}$

\subsubsection{A autonomia e a eficiência gerencial das agências reguladoras}

Não só de produção de normas vive uma agência. Do ponto de vista gerencial, as agências precisam de recursos próprios para que possam tomar decisões empiricamente bem informadas. Isso envolve, por certo, determinada discricionariedade para alocação de seus recursos em pessoal e na contratação de terceiros para treinamentos, estudos, bens e serviços em geral. É dizer: a autonomia financeira é essencial para o êxito de uma agência reguladora. É nesse contexto, aliás, que tais instituições têm passado

47 Sobre o tema, v. MOREIRA, Egon Bockmann; CAGGIANO, Heloisa Conrado. O poder normativo das agências reguladoras na jurisprudência do STF - Mutação constitucional do princípio da legalidade? Revista de Direito Público da Economia - RDPE, Belo Horizonte, ano 11, n. 43, jul./set. 2013. 
a sofrer diversos reveses que as enfraquecem do ponto de vista institucional, sobretudo por meio de contingenciamento de receitas. ${ }^{48}$

A autonomia gerencial das agências reguladoras foi objeto de exame em duas oportunidades pelo Supremo Tribunal Federal: (i) uma em relação aos seus processos de contratação, mais especificamente em relação a dispositivos que previam regras específicas de licitações para a ANATEL (ADI no 1668); e (ii) outra em relação aos regime de pessoal das agências reguladoras como um todo, em ação que discutia a constitucionalidade do regime celetista de seus agentes burocráticos (ADI n²310).

Quanto à possibilidade de previsão de regras específicas de contratações administrativas em favor das agências reguladoras, o STF, por maioria, adotou entendimento favorável à autonomia gerencial da ANATEL. Os arts. 22, inciso II, 54 a 59, 89, 119 e 210 da Lei n 9.472/1997 previam a possibilidade de adoção de duas modalidades não existentes na então Lei Geral de Licitações e Contratos (Lei n 8.666/1993): o pregão e a consulta, incluindo-se a possibilidade de edição de atos normativos pela agência para discipliná-los na via infralegal. A apertada decisão da Corte garantiu que a ANATEL pudesse realizar contratações mais eficientes, sendo este um dos raros casos no Brasil em que a abertura de experiências institucionais isoladas pudessem ser ampliadas para toda as Administrações Públicas nacionais a partir da constatação dos resultados positivos da política adotada ${ }^{49}$.

Embora o caso não tenha sido levado a Plenário (as normas impugnadas foram posteriormente revogadas), a ADI n 2310 também tem uma importância acentuada ${ }^{50}$ quanto ao tema da autonomia gerencial das agências reguladoras. Referida ação tinha por objeto dispositivos da Lei n 9.986/2000 que continham previsões sobre a gestão de recursos humanos das agências reguladoras, mais especificamente aqueles que submetiam o regime de pessoal das entidades às regras da Consolidação das Leis do Trabalho, afastando-se o regime estatutário próprio das autarquias. Dito de outra forma, os autores da ação defendiam que o exercício da função de fiscalização, inerente à atividade precípua do Estado, pressupunha prerrogativas não agasalhadas pelo contrato de trabalho. A tese foi encampada pelo Ministro Marco Aurélio, para quem somente

\footnotetext{
48 Sobre o tema, recomendamos, novamente, a leitura de JORDÃO, Eduardo; RIBEIRO, Maurício Portugal. Como desestruturar uma agência reguladora em passos simples. Revista Estudos Institucionais, v. 3, n. 1, p. 180-209, ago. 2017.

49 De fato, o indeferimento da medida cautelar em relação à modalidade pregão permitiu que a ANATEL editasse normas disciplinando o seu procedimento, conforme o seu Regulamento de Contratações (Resolução $n^{\circ}$ 05/1998). Em verdade, foi somente com a edição da Medida Provisória n 2.026/2000 que se estendeu a aplicação do pregão para toda a Administração Pública Federal, a partir das boas experiências constatadas pela agência na aplicação da modalidade. Significa dizer que a autonomia gerencial garantida à agência reguladora quanto ao tema trouxe externalidades positivas inclusive no tema de contratações pública em geral.

50 A relevância do julgado transborda o tema das agências reguladoras. Recentemente, em ação que envolve a discussão sobre o exercício do poder de polícia por empresas estatais, o Ministro Luiz Fux citou a ADI $n^{\circ}$ 2310 como fundamento da relevância do tema para fins de reconhecimento de sua repercussão geral (v. ARE 662186 RG, Rel. Min. Luiz Fux, j. em 22/03/2012, DJe 13/09/2012).
} 
o cargo público propicia desempenho técnico, isento e imparcial necessário para a atuação pública das agências reguladoras ${ }^{51}$.

Por fim, registre-se o julgamento sobre uma questão relevante que envolve a eficiência gerencial de uma agência reguladora. O art. 26, §3 da Lei no 9.478/1997 prevê uma hipótese de efeitos positivos ao silêncio administrativo da ANP em casos de submissão de planos e projetos de desenvolvimento e produção na exploração de petróleo ou gás natural. ${ }^{52} \mathrm{O}$ objetivo desta norma é evitar a inércia da agência nestes procedimentos, garantindo a celeridade de seus órgãos na análise dos pleitos relativos à matéria. Por maioria, o Supremo Tribunal Federal legitimou este mecanismo no bojo das ADIs nos 3273 e 3366.

\subsubsection{Usurpação de competências de outros Poderes}

Por fim, é necessário registrar casos em que o Supremo Tribunal Federal debateu a constitucionalidade de competências específicas de agências reguladoras que foram contestados por usurpar poderes específicos reservados a outras instituições: o Poder Judiciário e o (chefe do) Poder Executivo.

Na ADI no 1668, a liminar foi deferida em relação ao poder de realização de busca e apreensão pela ANATEL. No entender da Corte, embora as agências reguladoras possuam competências fiscalizatórias, não se pode compreender, nela, a realização de busca e apreensão de bens de terceiros, matéria essa sujeita à reserva de jurisdição. $\mathrm{O}$ Plenário afirmou, assim, que somente o Poder Judiciário poderia realizar atos de constrição do gênero. Por isso, o STF suspendeu, cautelarmente, o disposto no art. 19, inciso XV da Lei da ANATEL.

51 "Hão de estar as decisões desses órgãos imunes a aspectos políticos, devendo fazer-se presente, sempre, o contorno técnico. É isso o exigível não só dos respectivos dirigentes - detentores de mandato -, mas também dos servidores - reguladores, analistas de suporte à regulação, procuradores, técnicos em regulação e técnicos em suporte à regulação - Anexo I da Lei no 9.986/2000 - que, juntamente com os primeiros, hão de corporificar o próprio Estado nesse mister da mais alta importância, para a efetiva regulação dos serviços. Prescindir, no caso, da ocupação de cargos públicos, com os direitos e garantias a eles inerentes, é adotar flexibilidade incompatível com a natureza dos serviços a serem prestados, igualizando os servidores das agências a prestadores de serviços subalternos, dos quais não se exige, até mesmo, escolaridade maior, como são serventes, artífices, mecanógrafos, entre outros (...) Em suma, não se coaduna com os objetivos precípuos das agências reguladoras, verdadeiras autarquias, embora de caráter especial, a flexibilidade inerente aos empregos públicos, impondo-se a adoção da regra que é a revelada pelo regime de cargo público, tal como ocorre em relação a outras atividades fiscalizadoras - fiscais do trabalho, de renda, servidores do Banco Central, dos Tribunais de Conta, etc." (ADI 2310, Rel. Min. Marco Aurélio, decisão monocrática proferida em 19/12/2000).

52 Art. 26. A concessão implica, para o concessionário, a obrigação de explorar, por sua conta e risco e, em caso de êxito, produzir petróleo ou gás natural em determinado bloco, conferindo-lhe a propriedade desses bens, após extraídos, com os encargos relativos ao pagamento dos tributos incidentes e das participações legais ou contratuais correspondentes. $§ 1^{\circ} \mathrm{Em}$ caso de êxito na exploração, o concessionário submeterá à aprovação da ANP os planos e projetos de desenvolvimento e produção. §2 ${ }^{\circ}$ A ANP emitirá seu parecer sobre os planos e projetos referidos no parágrafo anterior no prazo máximo de cento e oitenta dias. $\$ 3^{\circ}$ Decorrido o prazo estipulado no parágrafo anterior sem que haja manifestação da ANP, os planos e projetos considerar-se-ão automaticamente aprovados. 
Já nas ADIs n 3273 e 3366, uma competência especíica da ANP foi questionada por supostamente usurpar uma competência específica do chefe do Poder Executivo. Dentre outros aspectos sobre o marco regulatório no setor de petróleo e gás, os autores de ambas as ações diretas questionaram a competência da Agência Nacional do Petróleo para autorizar a exportação de petróleo (art. 60 da Lei n 9.478/1997). Ambos os autores defendiam que a competência em questão seria uma matéria de Estado (i.e., Administração Pública direta), não sujeito à reserva técnica da agência reguladora. Seria inconstitucional, portanto, deferir à agência reguladora uma questão que envolvesse essencialmente a soberania nacional. Como já mencionado, o STF, por maioria, julgou as ações improcedentes, reconhecendo o espaço de atuação da agência (condicionado, contudo, às políticas adotadas pelo Presidente da República em conformidade com as proposições do Conselho Nacional de Política Energética - CNPE).

\subsection{Quem e como decidem?}

A terceira e última questão a ser analisada em relação ao Supremo Tribunal Federal é a forma como se comportam os Ministros, tanto do ponto de vista das condutas individuais adotadas no curso de um processo que envolva a impugnação de uma lei que discipline o regime jurídico de uma agência reguladora, como do ponto de vista do posicionamento adotado em julgamentos sobre a matéria.

\subsubsection{A conduta individual dos Ministros}

Retomando-se a ideia das onze ilhas destacada acima, duas condutas tomadas individualmente por Ministros podem ter impacto direto em uma ação de controle abstrato, sem a necessidade de manifestação colegiada sobre o assunto ${ }^{53}$. São elas: (i) a tomada de decisões monocráticas por parte do relator; e (ii) os pedidos de vista formulados no curso do processo de deliberação do plenário do STF.

Em relação aos relatores, é necessário apontar, em primeiro lugar, uma curiosidade: a acentuada distribuição dos casos envolvendo agências reguladoras ao Ministro Marco Aurélio (7 em um total de 18). Como se verá abaixo, trata-se de um dos poucos membros do Supremo Tribunal Federal que possuem postura declaradamente contrária a uma ampla autonomia das agências reguladoras no ordenamento brasileiro.

53 Sobre o tema, v. SILVA, Virgílio Afonso da. Deciding without deliberating. I.CON, v. 11, n. 3, p. 557-584, 2011; FALCÃO, Joaquim; ARGUELHES, Diego. Onze Supremos: todos contra o plenário. In: FALCÃO, Joaquim; ARGUELHES, Diego W.; RECONDO, Felipe (Org.). Onze Supremos: o Supremo em 2016. Rio de Janeiro: Fundação Getúlio Vargas, 2017; ARGUELHES, Diego Werneck; RIBEIRO, Leandro Molhano. Ministrocracia?: o Supremo Tribunal individual e o processo democrático brasileiro. Novos estudos CEBRAP, v. 37, n. 1, 2018; NETO, José Mário Wanderley Gomes. LIMA, Flávia Danielle Santiago Lima. Das 11 ilhas ao centro do arquipélogo: os superpoderes do presidente do STF durante o recesso judicial e férias. Revista Brasileira de Políticas Públicas, v. 8 , n. 2, 2018. 
Em relação ao comportamento dos relatores em si, é possível apontar uma reduzida atuação monocrática. De um modo geral, adota-se o rito do art. 10 (em que a análise do pedido cautelar é postergado após a obtenção de informações das entidades legitimadas) ${ }^{54}$ ou o do art. 12 da Lei n 9.868/1999 (em que o relator, em face da relevância da matéria, entende que o caso deva ser julgado em definitivo, sem apreciação do pedido cautelar $)^{55}$. Em 10 de 16 ações em que medidas liminares foram pleiteadas, essa foi a posição adotada pelo relator.

\begin{tabular}{|c|c|c|c|c|c|}
\hline ADI & Relator & Liminar & $\begin{array}{l}\text { Resultado da } \\
\text { liminar }\end{array}$ & $\begin{array}{l}\text { Julgamen- } \\
\text { to }\end{array}$ & $\begin{array}{c}\text { Resul- } \\
\text { tado } \\
\text { final }\end{array}$ \\
\hline 6033 & ROBERTO BARROSO & Art. 10 & - & - & - \\
\hline 6006 & MARCO AURÉLIO & Art. 12 & - & - & - \\
\hline 5993 & MARCO AURÉLIO & Art. 12 & - & - & - \\
\hline 5906 & MARCO AURÉLIO & -56 & - & - & - \\
\hline 5372 & LUIZ FUX & Art. 12 & - & Sim & $\begin{array}{l}\text { Não } \\
\text { conhe- } \\
\text { cida }\end{array}$ \\
\hline 5371 & ROBERTO BARROSO & - & - & - & - \\
\hline 4874 & ROSA WEBER & Sim & $\begin{array}{l}\text { Deferida } \\
\text { monocratica- } \\
\text { mente }\end{array}$ & Sim & $\begin{array}{l}\text { Impro- } \\
\text { ceden- } \\
\text { te }\end{array}$ \\
\hline 4679 & LUIZ FUX & Art. 12 & - & Sim & $\begin{array}{l}\text { Proce- } \\
\text { dência } \\
\text { parcial }\end{array}$ \\
\hline 4226 & CELSO DE MELLO & Art. 12 & - & - & - \\
\hline 3596 & CÁRMEN LÚCIA & Art. 12 & - & - & - \\
\hline
\end{tabular}

54 Art. 10. Salvo no período de recesso, a medida cautelar na ação direta será concedida por decisão da maioria absoluta dos membros do Tribunal, observado o disposto no art. 22, após a audiência dos órgãos ou autoridades dos quais emanou a lei ou ato normativo impugnado, que deverão pronunciar-se no prazo de cinco dias.

55 Art. 12. Havendo pedido de medida cautelar, o relator, em face da relevância da matéria e de seu especial significado para a ordem social e a segurança jurídica, poderá, após a prestação das informações, no prazo de dez dias, e a manifestação do Advogado-Geral da União e do Procurador-Geral da República, sucessivamente, no prazo de cinco dias, submeter o processo diretamente ao Tribunal, que terá a faculdade de julgar definitivamente a ação.

56 Não foi formulado pedido cautelar na ADI n 5906 e na ADI n 5371. 


\begin{tabular}{|c|c|c|c|c|c|}
\hline 3366 & CARLOS BRITTO & -57 & - & Sim & $\begin{array}{l}\text { Impro- } \\
\text { ceden- } \\
\text { te }\end{array}$ \\
\hline 3273 & CARLOS BRITTO & Sim & $\begin{array}{l}\text { Deferida } \\
\text { monocratica- } \\
\text { mente }\end{array}$ & Sim & $\begin{array}{l}\text { Impro- } \\
\text { ceden- } \\
\text { te }\end{array}$ \\
\hline 3240 & MARCO AURÉLIO & Art. 12 & - & Sim & $\begin{array}{l}\text { Perda } \\
\text { do } \\
\text { objeto }\end{array}$ \\
\hline 2658 & DIAS TOFFOLI & Art. 12 & - & - & - \\
\hline 2543 & MAURÍCIO CORRÊA & - & - & Sim & $\begin{array}{l}\text { Não } \\
\text { conhe- } \\
\text { cida }^{58}\end{array}$ \\
\hline 2315 & MARCO AURÉLIO & Art. 10 & - & Sim & $\begin{array}{l}\text { Perda } \\
\text { do } \\
\text { objeto }\end{array}$ \\
\hline 2310 & MARCO AURÉLIO & Sim & $\begin{array}{c}\text { Deferida } \\
\text { monocratica- } \\
\text { mente }\end{array}$ & Sim & $\begin{array}{l}\text { Perda } \\
\text { do } \\
\text { objeto }\end{array}$ \\
\hline 1668 & MARCO AURÉLIO & $\operatorname{Sim}^{59}$ & $\begin{array}{l}\text { Deferida par- } \\
\text { cialmente pelo } \\
\text { Plenário }\end{array}$ & - & - \\
\hline
\end{tabular}

Em apenas três oportunidades a medida liminar foi concedida monocraticamente. A primeira delas foi a já relatada: ADI n²310, de relatoria do Ministro Marco Aurélio, em que dispositivos da Lei no 9.986/2000 foram suspensos para impedir a contratação de pessoal das agências pelo regime celetista, no ano de 2000. A segunda foi proferida pelo Min. Carlos Ayres Britto no bojo da ADI no 3273, em agosto de 2014, para suspender a eficácia de diversos dispositivos da Lei no 9.478/1997, em razão da ocorrência da 6a Rodada de Licitações das áreas produtoras de petróleo e gás natural. Já a terceira foi proferida pela Ministra Rosa Weber. Embora tenha inicialmente aplicado o rito do art. 12 da Lei no 9.868/199960 ao caso, a relatora deferiu a medida cautelar pleiteada pela

57 Decisão proferida na ADI n 3273, em apenso.

58 Decisão proferida logo após a distribuição do feito, sem apreciação do pedido cautelar.

59 A Lei no 9.868/1999 ainda não havia sido editada quando do início do julgamento do pedido cautelar.

60 Art. 12. Havendo pedido de medida cautelar, o relator, em face da relevância da matéria e de seu especial significado para a ordem social e a segurança jurídica, poderá, após a prestação das informações, no prazo de dez dias, e a manifestação do Advogado-Geral da União e do Procurador-Geral da República, sucessivamente, no prazo de cinco dias, submeter o processo diretamente ao Tribunal, que terá a faculdade de julgar definitivamente a ação. 
autora da ação por um fato superveniente: o Tribunal Regional Federal da $1^{\text {a }}$ Região confirmou a decisão antecipatória de tutela proferida pela 9a Vara Federal da Seção Judiciária de Brasília havia garantido a suspensão da eficácia da RDC no 14/2012 para parte do setor do mercado fumígeno. Assim, a relatora, em setembro de 2013, deferiu a suspensão integral de dispositivos da resolução a fim de assegurar tratamento isonômico a todos os potencialmente afetados pelos atos normativos impugnados. Nos três casos, condutas concretas (contratação de pessoal; realização de procedimentos licitatórios; e proibição de comercialização de cigarros com ingredientes específicos) deram ensejo ao deferimento dos pedidos.

Ainda quanto às decisões cautelares, não é possível apontar nenhum elemento adicional satisfatório que indique uma tendência decisória do Supremo Tribunal Federal. Um dado, contudo, desperta curiosidade: nenhum dos casos em que houve deferimento do pedido cautelar levou a um julgamento de mérito procedente: na ADI no 3273, o Ministro Eros Grau foi relator para acórdão; enquanto que na, ADI n 4874, a Ministra Rosa Weber julgou a demanda improcedente.

Passando ao segundo ponto, os pedidos de vista foram formulados em metade dos casos julgados pelo plenário do Supremo Tribunal Federal. Em ambas as hipóteses, os pedidos foram formulados para que os Ministros pudessem abrir divergência sobre o resultado final do julgamento (como nas ADIs ns 3273 e 3366), ou para um exame mais aprofundado da matéria em razão de prévia divergência suscitada por outro membro do tribunal (como na ADI no 4679).

Nas ADIs nos 3273 e 3366, julgadas conjuntamente, tanto o Ministro Marco Aurélio como o Ministro Eros Grau pediram vista no feito para que pudessem elaborar votos divergentes ao relator original do caso, o Ministro Carlos Ayres Britto. Já na ADI n 4679, o Ministro Dias Toffoli requereu vista para poder examinar, com maior apuro, a constitucionalidade do art. 25 da Lei n 12.485/2011, que não se relaciona ao tema das agências reguladoras, mas ao marco regulatório do setor de serviço de acesso condicionado. Ao final, o Ministro votou no mesmo sentido do relator, discordando da divergência aberta pelo Ministro Edson Fachin. Nesse último caso, o pedido de vista teve impacto significativo para o deslinde da ação, ampliando o tempo de tramitação do feito em mais de dois anos. 


\begin{tabular}{|c|c|c|c|}
\hline ADI & Pedidos de vista & Ministro & Tempo para deliberação \\
\hline 4874 & Não & - & - \\
\hline 4679 & $\operatorname{Sim}$ & DIAS TOFFOLI & 826 dias \\
\hline 3273 e 3366 & Sim & MARCO AURÉLIO & 160 dias \\
\hline 3273 e 3366 & Sim & EROS GRAU & 14 dias \\
\hline 1668 & Não & - & - \\
\hline
\end{tabular}

\subsubsection{O posicionamento individual dos Ministros}

Em relação ao entendimento jurídico específico dos Ministros da Corte, é possível notar que parte deles tem uma posição bem definida em relação ao modelo legal das agências independentes; enquanto outros, embora votem em sentido favorável às agências reguladoras, não o fazem com a exposição de razões contundentes.

Os Ministros Nelson Jobim e Moreira Alves foram aqueles que, no âmbito da ADI n 1668, apresentaram os principais contrapontos aos argumentos desfavoráveis ao modelo das agências reguladoras no Brasil. Atualmente, os Ministros Luiz Fux e Rosa Weber, aparentemente, foram aqueles que mais aprofundaram o debate sobre o tema nos acórdãos mais recentes. A circunstância de terem sido relatores, respectivamente, das ADIs n 4679 e 4874 permitiu um estudo mais denso sobre o tema, o que se reflete em parâmetros similares de interpretação - mesmo que, no mérito, seus votos venham a divergir. Foram eles, aliás, que incluíram expressamente em seus votos as orientações sobre a doutrina dos princípios inteligíveis ${ }^{61}$ e a teoria da deferência judicial aos atos das agências reguladoras ${ }^{62}$.

61 Segundo o Ministro Luiz Fux, "A moderna concepção do princípio da legalidade, em sua acepção principiológica ou formal axiológica, chancela a atribuição de poderes normativos ao Poder Executivo, desde que pautada por princípios inteligíveis (intelligible principles) capazes de permitir o controle legislativo e judicial sobre os atos da Administração" (ADI n 4679, Rel. Min. Luiz Fux, p. 4). Já para a Ministra Rosa Weber, "Sem se afastar do entendimento afirmado nos precedentes, conquanto razoável admitir que o princípio da reserva de lei inscrito no art. 50, II, da CF permita a delegação de funções normativas - e não legislativas - a entes de feição administrativa, não se pode dispensar a lei formalizadora da delegação de preestabelecer as diretrizes de tais competências mediante tipificação mínima do conteúdo normativo a ser integrado pela Administração. Dessa forma, pode-se afirmar que 1 delegações demasiado amplas não são compatíveis com referido princípio constitucional, por não oferecerem critérios para avaliar se a norma de competência foi ou não cumprida pela Administração"' (ADI n 4874 , voto da Min. Rosa Weber, p. 34).

62 Segundo o Ministro Luiz Fux, "o Poder Judiciário deve, como regra geral e em razão do que já exposto anteriormente, observar o princípio da deferência em relação aos atos das agências reguladoras. Os atos administrativos das agências, que resultam de escolhas técnicas tomadas por meio de uma deliberação colegiada e imparcial, devem ser respeitados pelos seus órgãos de controle, e nisso devemos incluir o Poder Judiciário" (ADI n 4874, voto do Ministro Luiz Fux, p. 161). Já para a Ministra Rosa Weber, "A doutrina da deferência administrativa, conhecida como Chevron deference porque sistematizada pela Suprema Corte dos EUA no julgamento do caso Chevron U.S.A., Inc. v. Natural Resources Defense Council, Inc., de 1984, orienta que, uma vez claramente definidos, na lei de regência, as políticas a serem perseguidas, os objetivos a serem implementados e os objetos específicos de tutela, ainda 
Em outro prisma, observa-se que o Ministro Marco Aurélio é, desde o início dos debates sobre o assunto no âmbito do STF, o Ministro que apresenta maior resistência ao regime jurídico especial das agências reguladoras. É verdade que o Ministro Marco Aurélio não ignora a possibilidade de delegação de competências técnicas para agências reguladoras. Assim, nas ADIs 3273 e 3366, o Ministro foi favorável ao poder da ANP de exportar petróleo. ${ }^{63}$ Tratava-se, contudo, de competência administrativa e executiva. Nos demais casos apreciados pelo Plenário, sua posição foi muito mais restritiva, em especial na ADI n 4874, em que o Ministro sustentou forte contestação contra a autonomia normativa das agências reguladoras ${ }^{64}$.

\begin{tabular}{|c|c|c|}
\hline Ministro & Posicionamento favorável & $\begin{array}{c}\text { Posicionamento con- } \\
\text { trário }\end{array}$ \\
\hline MARCO AURÉLIO & ADI 3273; ADI 3366; ADI 4679 & $\begin{array}{c}\text { ADI 1668; ADI 2310; ADI } \\
4874\end{array}$ \\
\hline CELSO DE MELLO & ADI 4679; ADI 4874 & ADI 1668 \\
\hline GILMAR MENDES & ADI 3273; ADI 3366; ADI 4679 & ADI 4874 \\
\hline RICARDO LEWANDOWSKI & ADI 4679; ADI 4874 & \\
\hline DIAS TOFFOLI & ADI 4679; ADI 4874 & \\
\hline CARMEN LÚCIA & ADI 4679; ADI 4874 & \\
\hline
\end{tabular}

que ausente pronunciamento direto, preciso e não ambíguo do legislador sobre as medidas específicas a adotar, não cabe ao Poder Judiciário, no exercício do controle jurisdicional da exegese conferida por uma Agência ao seu próprio estatuto legal, simplesmente substituí-la pela sua própria interpretação da lei. Sendo a lei ambígua com relação à questão específica, a questão a ser decidida pela Corte é se, ao acomodar interesses contrapostos, a solução a que chegou a agência foi devidamente fundamentada e se tem lastro em uma interpretação da lei razoável e compatível com a Constituição. Esse é o ponto" (ADI 4874, voto da Ministra Rosa Weber, p. 66).

63 Segundo sua manifestação, "(...) o setor petrolífero caracteriza-se pela alta especialização, a demandar um monitoramento constante. A criação da Agência Nacional do Petróleo como entidade reguladora, e conforme previsão constitucional, busca evitar práticas abusivas por parte das empresas privadas que poderão explorar petróleo, além de condutas anticoncorrenciais ou concentrações empresariais, bem como procura garantir a qualidade da produção, o abastecimento do mercado interno, a continuidade do serviço, o respeito às questões ambientais, sempre em prol da preservação do interesse público" (ADI n 3272, voto do Min. Marco Aurélio, p. 205). Interessante apontar que o Ministro Marco Aurélio - o mesmo que havia imposto uma série de condicionantes à atuação da ANATEL no bojo da ADI no 1668 -, foi o primeiro (e único) a expressamente defender a competência ampla da ANP quanto à questão posta nas ADIs n 3273 e n 3366, reconhecendo a importância das agências reguladoras em questões eminentemente técnicas e especializadas.

64 "O princípio da legalidade é o lastro de um Estado Democrático de Direito. Ninguém é obrigado a fazer ou deixar de fazer alguma coisa senão em virtude de lei. A atuação das agências faz-se no campo executivo; é atuação em campo específico, é fiscalizadora. Não se pode conceber - e já foi evocado o artigo 25 do Ato das Disposições Constitucionais Transitórias - delegação, muito menos às agências, para que normatizem! E esse artigo versa - e não se estabeleça distinção entre normatizar e impor norma legal propriamente dita - que não pode haver delegação, a quem quer que seja, de atribuição do Congresso Nacional. E cabe apenas ao Congresso Nacional, em que pese o precedente sobre o amianto, proibir algum produto no território brasileiro, por melhor que seja a intenção que impere" (ADI n 4874, voto do Ministro Marco Aurélio, p. 186). 


\begin{tabular}{|c|c|c|}
\hline LUIZ FUX & ADI 4679; ADI 4874 & \\
\hline ROSA WEBER & ADI 4679; ADI 4874 & \\
\hline ROBERTO BARROSO & ADI 4679 & \\
\hline ALEXANDRE DE MORAES & ADI 4874 & \\
\hline EDSON FACHIN & ADI 4679; ADI 4874 & \\
\hline NELSON JOBIM & ADI 1668; ADI 3273; ADI 3366 & \\
\hline ILMAR GALVÃO & ADI 1668 & \\
\hline OCTÁVIO GALLOTTI & ADI 1668 & \\
\hline SYDNEY SANCHES & ADI 1668 & \\
\hline MOREIRA ALVES & ADI 1668 & \\
\hline CARLOS VELLOSO & ADI 3273; ADI 3366 & ADI 1668 \\
\hline SEPÚLVEDA PERTENCE & ADI 3273; ADI 3366 & ADI 1668 \\
\hline NÉRI DA SILVEIRA & & ADI 1668 \\
\hline MAURÍCIO CORRÊA & & ADI 1668 \\
\hline CARLOS BRITTO & & ADI 3273; ADI 3366 \\
\hline JOAQUIM BARBOSA & ADI 3273; ADI 3366 & ADI 3273; ADI $3366^{65}$ \\
\hline EROS GRAU & ADI 3273; ADI 3366 & \\
\hline ELLEN GRACIE & ADI 3273; ADI 3366 & \\
\hline CEZAR PELUSO & ADI 3273; ADI 3366 & \\
\hline TEORI ZAVASCKI & ADI 4679 & \\
\hline
\end{tabular}

De mais a mais, a partir da ADI n 4874, é possível identificar que as divergências entre as posições individuais dos Ministros aparecem mais no exame de atos concretos do que na disciplina legal das agências reguladoras. ${ }^{66}$ Há ao menos três grupos distin-

65 Joaquim Barbosa votou contra a constitucionalidade da hipótese de silêncio administrativo prevista no art. $26, \S 3^{\circ}$ da Lei do Petróleo.

66 De fato, a ADI n 4874 tinha um elemento adicional no pedido formulado pela autora: a declaração de inconstitucionalidade por arrastamento da Resolução da Diretoria Colegiada (RDC) da ANVISA n 14/2012, que dispõe sobre a restrição do uso de aditivos nos produtos fumígenos derivados do tabaco - ato normativo editado com base nas competências legais impugnadas na ação. Para a CNI, somente a lei em sentido formal - e não atos normativos infralegais - pode banir, proscrever ou limitar o desempenho de atividade econômica e, mesmo assim, para ser válida, esta lei deveria ser proporcional e razoável. Ao contrário dos demais julgados apontados acima, a ADI n 4874 foi a primeira em que o Supremo Tribunal Federal se debruçou exclusivamente sobre o poder normativo de uma agência reguladora. De fato, as ADIs $n^{\circ} 1668, n^{\circ} 3273, n^{\circ} 3366$ e $n^{\circ}$ 
tos em razão dos fundamentos que foram apresentados e dos votos que foram proferidos para o caso.

O primeiro, capitaneado pela Ministra relatora Rosa Weber, defendeu o poder normativo das agências reguladoras e, no caso concreto, entendeu existir parâmetros suficientes para a edição do ato normativo pela ANVISA. Seguiram esta orientação os Ministros Edson Fachin, Ricardo Lewandowski, Celso de Mello e Carmen Lúcia. O segundo grupo, capitaneado pelo Ministro Alexandre de Moraes e pelo Ministro Luiz Fux, embora tenha considerado o desenho institucional das agências reguladoras algo compatível com a Constituição Federal - e até desejável -, julgaram a demanda procedente em relação à declaração de inconstitucionalidade da RDC no 14/2012. Neste grupo, também está incluído o Ministro Dias Toffoli. Já o terceiro grupo é composto pelos Ministros Marco Aurélio e Gilmar Mendes, esse último, em sua primeira manifestação contrária às agências reguladoras nos casos pesquisados ${ }^{67}$. Em ambos os votos, foram apresentadas críticas contundentes à atuação das agências reguladoras, o que os levou a julgar a demanda procedente, em relação ao primeiro, e parcialmente procedente, em relação ao segundo.

Significa dizer que, do ponto de vista estratégico, a apresentação de atos concretos das agências reguladoras pode induzir e alterar a interpretação sobre os limites dos poderes regulatórios em abstrato. Tais assertivas, contudo, demandam melhor comprovação empírica no futuro, quando mais casos relacionados às agências reguladoras serão julgados pelo Supremo Tribunal Federal.

\subsection{Conclusões parciais em relação ao STF}

O escasso espaço amostral de julgamentos do STF em relação às ações pesquisadas impede que conclusões mais assertivas sejam firmadas. Contudo, os elementos apresentados neste item 4 permitem apontar algumas diretrizes sobre o poder decisório do Supremo Tribunal Federal.

4679 tinham escopo mais amplo, e discutiam também aspectos específicos do setor de telecomunicações, de petróleo e de comunicação audiovisual. Isso permite que seja possível identificar com maior precisão qual o posicionamento de cada Ministro em relação ao tema, na medida em que seus votos se dedicaram essencialmente a esta questão.

67 "Essa é a questão que se coloca, portanto, a questão da legalidade estrita. Isso é relevante, relevantíssimo. Porque veja a consequência até em termos de representatividade. Se um órgão desse jaez pode simplesmente decidir que determinada atividade fica autorizada ou proibida, nós estamos suprimindo, ainda que houvesse delegação, 0 poder do Congresso de legislar sobre isso, e estamos transferindo a um órgão burocrático. Esse é um problema seríssimo do ponto de vista constitucional. Eu tenho dito que hoje, no Brasil, ser revolucionário é defender o princípio da legalidade, fazer cumprir a lei. Ser progressista é defender a lei e não ficar inventando 'cositas.' Então é disso que se cuida! E aqui é uma questão... 'Ah, simplesmente aquela fábrica fechou, porque a ANVISA decidiu.' E é no interesse do público. Afinal, proibiu-se agora salsicha com dado produto, ou, sei lá, alguma outra coisa. Será que é esse o sistema que herdamos e que queremos preservar? Um modelo dessa feição autárquica? Não me parece que seja assim e essa é a questão que se coloca a partir do voto do Ministro Alexandre. Porque, realmente, ao fim e ao cabo, isso vai envolver uma supressão do poder do Congresso Nacional" (ADI n 4874, voto do Ministro Gilmar Mendes, p. 180). 
Em relação ao fator tempo, é possível identificar que os processos relacionados ao regime jurídico das agências reguladoras possuem longo tempo de tramitação; e que os casos que já foram julgados até então geralmente tomam elevado tempo do plenário, todos eles em mais de uma sessão do colegiado. A linha do tempo dos casos também demonstra dois blocos de períodos distintos em que se concentraram as decisões sobre o tempo: o primeiro, em um período de afirmação do modelo das agências reguladoras (1998-2005); e o segundo, em um período de consolidação e aprimoramento deste modelo institucional (2013-2018).

Em relação à orientação geral do STF no exame sobre as leis que disciplinam o regime jurídico das agências reguladoras, é possível afirmar que o histórico de decisões da Corte indica que o modelo geral das agências reguladoras é compatível com a Constituição Federal. A evolução de sua concepção, contudo, é perceptível: se antes as agências reguladoras eram uma possibilidade legislativa e o exercício de suas competências normativas estavam submetidas à estrita legalidade, a evolução da jurisprudência do Supremo Tribunal Federal leva ao reconhecimento da importância institucional das agências reguladoras no desenvolvimento social e ao estabelecimento de parâmetros específicos para o bom exercício do seu poder normativo.

De um modo geral, o STF reconhece que as agências reguladoras representam um desenho institucional voltado para o exercício do poder regulatório sobre questões técnicas específicas. No entanto, as competências extraordinárias de tais entidades somente serão válidas quando existentes e observados os parâmetros previstos em lei (princípios inteligíveis). E mais: autonomia das agências reguladoras não impossibilita posterior revisão de seus atos pelo Poder Judiciário, mesmo que seja recomendável a adoção de uma postura deferente para a reavaliação de decisões técnicas das agências.

Por fim, em relação aos Ministros, é possível apontar uma tendência acentuada à deliberações colegiadas sobre o assunto, registrando-se poucos casos de deferimento de pedidos cautelares monocraticamente. No mais, os pedidos de vista são utilizados geralmente para que os membros do tribunal possam apresentar posições divergentes daquelas apresentadas por outros Ministros da Corte. Por fim, destaca-se o posicionamento acentuado dos Ministros Luiz Fux e Rosa Weber em defesa do modelo institucional das agências reguladoras na atual composição do STF, entendimento esse seguido por grande maioria. A exceção fica com o Ministro Marco Aurélio - curiosamente, relator de grande número de ações sobre o caso -, que apresentou posicionamentos e fundamentações mais contundentes em sentido contrário ao regime jurídico especial das agências reguladoras. 


\section{CONCLUSÕES}

Passados mais de vinte anos desde a adoção do modelo institucional das agências reguladoras no Brasil, ainda não há respostas definitivas sobre os limites impostos aos seus regimes jurídicos. A escassez de casos examinados nesta pesquisa, contudo, não retira o valor das suas conclusões. Pelo contrário: o número reduzido de casos demonstra que, embora o Supremo Tribunal Federal seja um foro relevante para o debate sobre o regime jurídico das agências reguladoras, o uso cauteloso dessa via pelos agentes legitimados torna ainda mais crucial o estudo dos dados sobre os postulantes destas ações e sobre o poder decisório do STF.

Do ponto de vista dos postulantes, este artigo demonstrou que a ADI é uma ferramenta para um debate essencialmente político sobre as agências reguladoras, sendo o Supremo Tribunal Federal um foro relevante para deflagrar tal discussão de forma célere e imediata. Ainda sob a ótica dos postulantes, foi possível notar que os setores regulados, embora não sejam necessariamente contrários ao modelo das agências reguladoras no Brasil, vêm tentando diminuir o alcance de seu poder em casos específicos, muitas vezes diante de algum elemento contextual que torna esta contestação oportuna. De todo modo, o volume de casos ajuizados perante o Supremo Tribunal Federal não revela ainda nenhum padrão - as demandas, quase sempre, estão relacionadas a elementos contingentes que justificam a busca pela jurisdição constitucional.

Já em relação à atuação Supremo Tribunal Federal, é possível notar que a Corte reconhece a constitucionalidade do regime jurídico especial das agências reguladoras. De um modo geral, sua jurisprudência encontra-se em fase de consolidação de um modelo voltado ao aprimoramento do regime jurídico de tais entidades. Reconhece-se, assim, (i) a constitucionalidade da atribuição de competências técnicas às agências reguladoras; (ii) a necessidade de que seus poderes estejam sujeitos à observância às regras de direito público e aos parâmetros previstos em leis setoriais; e (iii) o fato de que sua independência não afasta a possibilidade de posterior controle de seus atos, ainda que seja recomendável a adoção de uma postura deferente do Poder Judiciário.

Tal como qualquer estudo empírico, este artigo não pretendeu apresentar respostas definitivas sobre o assunto. Ainda assim, investigar os elementos do passado é essencial para buscar indícios sobre o futuro, sobretudo porque o debate sobre o regime jurídico especial das agências reguladoras volta constantemente à tona na doutrina, na sociedade e, inevitavelmente, também no Supremo Tribunal Federal. 


\section{REFERÊNCIAS}

ARAGÃO, Alexandre Santos de. Agências reguladoras e a evolução do direito administrativo econômico. 1. ed. Rio de Janeiro: Forense, 2002.

ARAGÃO, Alexandre Santos de. O poder normativo das agências reguladoras. A\&C - Revista de Direito Administrativo \& Constitucional, Curitiba, ano 2, n. 7, p. 47-92, 2001.

ARGUELHES, Diego Werneck; RIBEIRO, Leandro Molhano. Ministrocracia?: o Supremo Tribunal individual e o processo democrático brasileiro. Novos estudos CEBRAP, v. 37, n. 1, 2018.

AZEVEDO, Eurico de Andrade. Agências Reguladoras. Revista de Direito Administrativo - RDA, Rio de Janeiro, n. 213, p. 141-148, jul./set. 1998.

BARROSO, Luís Roberto. Agências Reguladoras. Revista de Direito Administrativo - RDA, Rio de Janeiro, n. 229, p. 285-311, 2002.

BINENBOJM, Gustavo (Coord.). Agências reguladoras e democracia. 1. ed. Rio de Janeiro: Lumen Juris, 2006.

BINENBOJM, Gustavo. Uma Teoria do Direito Administrativo. 3. ed. Rio de Janeiro: Renovar, 2014.

CONFORTO, Glória. Descentralização e Regulação da Gestão de Serviços Públicos. Revista de Administração Pública - RAP, vol. 32, n. 1, p. 27-40, 1998.

CYRINO, André. Delegações legislativas, regulamentos e Administração Pública. Belo Horizonte: Fórum, 2018.

DI PIETRO, Maria Sylvia Zanella. Curso de direito administrativo. 24. ed. São Paulo: Atlas, 2011.

FAERMANN, Patrícia. Roberto Requião critica projeto de Temer de “neoliberal”. 2016. Disponível em: <https://bit.ly/30JJs3Y>. Acesso em: 19 mar. 2019.

FALCÃO, Joaquim; ARGUELHES, Diego. Onze Supremos: todos contra o plenário. In: FALCÃO, Joaquim; ARGUELHES, Diego W.; RECONDO, Felipe (Org.). Onze Supremos: o Supremo em 2016. Rio de Janeiro: Fundação Getúlio Vargas, 2017.

GUERRA, Sérgio. Agências Reguladoras: da organização administrativa piramidal à governança em rede. 1. ed. Belo Horizonte: Fórum, 2012.

JORDÃO, Eduardo; RIBEIRO, Maurício Portugal. Como desestruturar uma agência reguladora em passos simples. Revista Estudos Institucionais, v. 3, n. 1, p. 180-209, ago. 2017.

JUSTEN FILHO, Marçal. Curso de Direito Administrativo. 5. ed. Belo Horizonte: Fórum, 2011. p. 655.

JUSTEN FILHO, Marçal. O Direito das Agências Reguladoras Independentes. São Paulo, SP: Dialética, 2002. 
KING, Jeff A. Institutional approaches to judicial restraint. Oxford Journal of Legal Studies, vol. 28, n. 3, p. 409-441, 2008.

LOURENÇO, Adriana Nickel. Regendo a atividade regulatória: a nova legislação das agências reguladoras federais no Brasil. Dissertação (Mestrado em Administração Pública), 2010. Escola Brasileira de Administração Pública e de Empresas - Fundação Getúlio Vargas. Disponível em <https://bit.ly/2EzyPqP>. Acesso em 19 mar. 2019.

MAJONE, Giandomenico. Do Estado positivo ao Estado regulador: causas e conseqüências de mudanças no modo de governança. Revista do Serviço Público, v. 50, n. 1, p. 5-36, 1999.

MARQUES NETO, Floriano de Azevedo. Agências reguladoras independentes: fundamentos e seu regime jurídico. 1. ed. Belo Horizonte: Fórum, 2005.

MARRARA, Thiago. A legalidade na relação entre ministérios e agências reguladoras. Revista da Faculdade de Direito da USP, São Paulo, n. 99, p. 723-746, jan./dez. 2004.

MATTOS, Paulo Todescan Lessa. O Novo Estado Regulador no Brasil: eficiência e legitimidade. São Paulo: Singular, 2006.

MORAES, Alexandre de. Agências reguladoras. Fórum Administrativo, Belo Horizonte, vol. 1, n. 8, p. 1009-1016, 2001.

MOREIRA NETO, Diogo de Figueiredo. Agências reguladoras. In: MOREIRA NETO, Diogo de Figueiredo. Mutações do Direito Administrativo. Rio de Janeiro: Renovar, 2000.

MOREIRA, Egon Bockmann; CAGGIANO, Heloisa Conrado. O poder normativo das agências reguladoras na jurisprudência do STF - Mutação constitucional do princípio da legalidade? Revista de Direito Público da Economia - RDPE, Belo Horizonte, ano 11, n. 43, jul./set. 2013.

MORENO, Jorge Bastos. Irritado com a Anac, Lula anuncia medidas fortes amanhã. 2007. Disponível em: <https://glo.bo/2HCKXJX>. Acesso em: 19 mar. 2019.

NETO, José Mário Wanderley Gomes. LIMA, Flávia Danielle Santiago Lima. Das 11 ilhas ao centro do arquipélogo: os superpoderes do presidente do STF durante o recesso judicial e férias. Revista Brasileira de Políticas Públicas, v. 8, n. 2, 2018.

PEREZ, Marcos Augusto. As agências reguladoras no direito brasileiro. A\&C - Revista de Direito Administrativo \& Constitucional, Curitiba, ano 2, n. 5, p. 59-66, 2000.

SCHYMURA renuncia à vaga no conselho da Anatel. 2004. Disponível em: <https://bit.ly/ 2Qobltu>. Acesso em: 19 mar. 2019.

SILVA, Virgílio Afonso da. Deciding without deliberating. I.CON, v. 11, n. 3, p. 557-584, 2011.

SOUTO, Marcos Juruena Villela. Agências reguladoras. Revista de Direito Administrativo - RDA, Rio de Janeiro, n. 216, p. 125-162, 1999. 
SUNDFELD, Carlos Ari. Introdução às Agências Reguladoras. In: Carlos Ari Sundfeld (Org.). Direito Administrativo Econômico. São Paulo, Malheiros, 2000. p. 17-38.

TÁCITO, Caio. Agências reguladoras da Administração. Revista de Direito Administrativo - RDA, Rio de Janeiro, n. 221, p. 1-5, 2000.

WALD, Arnoldo. A autonomia das agências reguladoras. Consulex: Revista Jurídica, v. 8, n. 170, p. 42-43, fev. 2004. 